\title{
The mantle source of basalts from Reunion Island is not more oxidized than the MORB source mantle
}

\author{
Maryjo Brounce $^{1}\left[\right.$ [D Edward Stolper ${ }^{2} \cdot$ John $^{\text {Eiler }}{ }^{2}$
}

Received: 16 August 2021 / Accepted: 26 November 2021 / Published online: 17 December 2021

(c) The Author(s) 2021

\begin{abstract}
Glasses quenched from relatively undegassed ocean island magmas erupted from volcanoes at Iceland, Hawaii, the Canary Islands, and Erebus have elevated $\mathrm{Fe}^{3+} / \sum \mathrm{Fe}$ ratios compared to glasses quenched from mid-ocean ridge basalts. This has been ascribed to elevated $f \mathrm{O}_{2}$ of their mantle sources, plausibly due to subducted, oxidized near-surface-derived components in their mantle sources. The basaltic magmas from Reunion Island in the Indian ocean have $\mathrm{Sr}-\mathrm{Nd}-\mathrm{Hf}-\mathrm{Pb}-\mathrm{Os}$ isotopic compositions suggesting that their mantle sources contain little or no subducted near-surface materials and contain the $\mathrm{C} /$ FOZO/PREMA mantle component. To constrain the $f_{2}$ of the C/FOZO/PREMA mantle component and test the link between oxidized OIB and recycled surface-derived materials in their sources, we measured major and volatile element abundances and $\mathrm{Fe}^{3+} / \sum \mathrm{Fe}$ ratios of naturally glassy, olivine-hosted melt inclusions from Piton de La Fournaise volcano, La Reunion. We conclude that the $f_{2}$ of the mantle source of these Reunion lavas is lower than of the mantle sources of primitive, undegassed magmas from Hawaii, Iceland, the Canary Islands, and Mt. Erebus, and indistinguishable from that of the Indianocean upper mantle. This finding is consistent with previous suggestions that the source of Reunion lavas (and the C/FOZO/ PREMA mantle component) contains little or no recycled materials and with the suggestion that recycled oxidized materials contribute to the high $f \mathrm{O}_{2}$ of some other OIBs, especially those from incompatible-element-enriched mantle sources. Simple mixing models between oxidized melts of EM1 and HIMU components and relatively reduced melts of DMM can explain the isotopic compositions and $\mathrm{Fe}^{3+} / \sum \mathrm{Fe}$ ratios of lavas from Hawaii, Iceland, the Canary Islands, and Mount Erebus; this model can be tested by study of additional OIB magmas, including those rich in the EM2 component.
\end{abstract}

Keywords Ocean island basalts $\cdot$ Mantle plumes $\cdot$ Redox $\cdot$ Oxygen fugacity $\cdot$ Mantle heterogeneity

\section{Introduction}

Measurements of the ratio of $\mathrm{Fe}^{3+}$ to total $\mathrm{Fe}$ (i.e., $\mathrm{Fe}^{3+} /$ $\left[\mathrm{Fe}^{2+}+\mathrm{Fe}^{3+}\right]$, or $\left.\mathrm{Fe}^{3+} / \sum \mathrm{Fe}\right)$ in basaltic glasses from ocean island volcanoes (OIBs-Hartley et al. 2017; Shorttle et al. 2015; Brounce et al. 2017; Helz et al. 2017; Moussallam et al. 2014, 2016, 2019) range from low values similar to those of mid-ocean ridge basalts (MORBs - 0.10-0.14; Berry et al. 2018; Zhang et al. 2018) to higher values that

Communicated by Dante Canil.

Maryjo Brounce

mbrounce@ucr.edu

1 Department of Earth and Planetary Sciences, University of California Riverside, Riverside, CA 92592, USA

2 Division of Geological and Planetary Sciences, California Institute of Technology, Pasadena, CA 91125, USA exceed those of subduction zone magmas (Fig. 1a; e.g., arc basalts 0.28; Brounce et al. 2014). This range in OIBs is sometimes recorded in samples from the same volcano, from the same island, and/or island group (Brounce et al. 2017; Moussallam et al. 2014; Shorttle et al. 2015; Novella et al. 2020), and even from the same eruption (Hartley et al. 2017; Helz et al. 2017). Moreover, for any given OIB volcano, glasses with the lowest $\mathrm{S}$ and $\mathrm{H}_{2} \mathrm{O}$ concentrations typically have the lowest $\mathrm{Fe}^{3+} / \sum \mathrm{Fe}$; this correlation of $\mathrm{Fe}^{3+} / \sum \mathrm{Fe}$ ratios with volatile contents has been attributed to reduction that is driven by loss of $\mathrm{S}$ during volcanic degassing (Anderson and Wright 1972; Brounce et al. 2017; Carmichael and Ghiorso 1986; Gaillard et al. 2011; Hartley et al. 2017; Helz et al. 2017; Moussallam et al. 2014, 2016, 2019; Shorttle et al. 2015; Novella et al. 2020). Figure 1a shows that the $\mathrm{Fe}^{3+} / \sum \mathrm{Fe}$ ratios of the least degassed glasses range from 0.17 in Icelandic glasses (Hartley et al. 2017; Shorttle et al. 2015; Novella et al. 2020) to as high as 0.30 in 

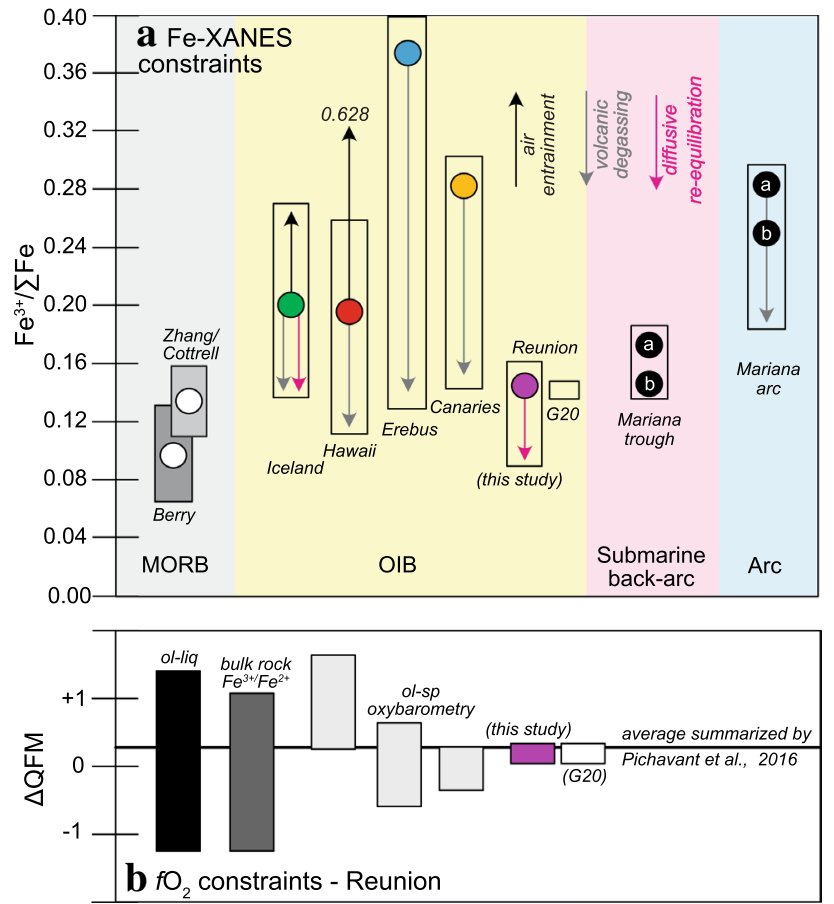

glasses from the Canary Islands (Moussallam et al. 2019), corresponding to oxygen fugacities $\left(f \mathrm{O}_{2} \mathrm{~s}\right)$ between 0.4 and 2.1 orders of magnitude higher than the quartz-fayalite-magnetite buffer (referred to as $\Delta \mathrm{QFM}$ values of +0.4 and +2.1 ) . The $f \mathrm{O}_{2}$ values of undegassed Hawaiian $\left(\mathrm{Fe}^{3+} / \sum \mathrm{Fe}=0.18\right.$; $\Delta \mathrm{QFM}=+0.6$; Brounce et al. 2017; Moussallam et al. 2016) and Mount Erebus $\left(\mathrm{Fe}^{3+} / \sum \mathrm{Fe}=0.40 ; \Delta \mathrm{QFM}=+2.0\right.$; Moussallam et al. 2014) glasses are between these extremes. In contrast, as summarized in Fig. 1a, wherever they have been sampled, MORB glasses have lower $\mathrm{Fe}^{3+} / \sum \mathrm{Fe}$ ratios, and although the exact average value is debated (ranging from $\mathrm{Fe}^{3+} / \sum \mathrm{Fe}=0.10$, Berry et al. 2018, to 0.14, Zhang et al. 2018), there is agreement that MORBs record $f \mathrm{O}_{2} \mathrm{~s}$ of $\Delta \mathrm{QFM}=-0.7$ to +0.1 (Cottrell and Kelley 2011; O'Neill et al. 2018; Zhang et al. 2018; Birner et al. 2018). The higher $\mathrm{fO}_{2} \mathrm{~s}$ of relatively undegassed glasses from ocean island basalts (OIBs) relative to MORB glasses have been interpreted as having been inherited from their mantle sources and attributed to the presence of recycled surface-derived and oxidized materials in their mantle sources (Brounce et al. 2017; Hartley et al. 2017; Helz et al. 2017; Moussallam et al. 2014, 2016, 2019; Shorttle et al. 2015; Novella et al. 2020).

Suites of OIB magmas generally define linear arrays in plots of radiogenic isotope ratios, and these have been interpreted as indicating that the Earth's mantle contains several isotopically distinct reservoirs or components that make variable contributions to the mantle sources of any given suite. For example, as shown in Fig. 2, Hawaiian and
4 Fig. 1 Summary of the ranges of $\mathrm{Fe}^{3+} / \sum \mathrm{Fe}$ measured via XANES in submarine pillow glass, matrix glass, and glassy inclusions hosted in minerals in a a global collection of MORB, OIB, back-arc basin, and arc basalts, and $\mathbf{b}$ Reunion island. Panel a: Circles in panel a are representations of the "most parental" values (least degassed) in each location. The rectangles for MORB correspond to the full range of the data and are from Cottrell and Kelley 2011, recalibrated according to Zhang et al. 2018 and Berry et al. 2018, and the circles represent each study's preferred average for globally representative sample sets. The values for OIB are from Hartley et al. 2017, Shorttle et al. 2015, (Iceland), Helz et al. 2017, Moussallam et al. 2016, Brounce et al. 2017 (Hawaii), Moussallam et al. 2014 (Erebus), Moussallam et al. 2019 (Canaries), and Reunion (this study, and Gaborieau et al. 2020; shown as G20 on the figure; XANES measurements of two olivine-hosted melt inclusions from a lava flow from Piton des Neiges, the other volcano that makes up Reunion Island). Various arrows and averages reflect the interpretations provided by each study. Gray downward pointing arrows indicate the extent of reduction in $\mathrm{Fe}^{3+} / \sum \mathrm{Fe}$ ratios as the result of degassing, black upward point arrows indicate the extent of oxidation in $\mathrm{Fe}^{3+} / \sum \mathrm{Fe}$ ratios as the result of the entrainment of air into surface exposed lava flows. Pink downward pointing arrow indicates the extent of reduction in $\mathrm{Fe}^{3+} / \sum \mathrm{Fe}$ ratios as the result of diffusive re-equilibration with a degassed host magma (see text). The values for the Mariana trough are from Brounce et al. (2014) and Kelley and Cottrell (2009). The black circle marked "a" corresponds to the average $\mathrm{Fe}^{3+} / \sum \mathrm{Fe}$ of subduction influenced back-arc submarine glasses, and the circle marked "b" corresponds to the average $\mathrm{Fe}^{3+} / \sum \mathrm{Fe}$ of non-subduction influenced back-arc submarine glasses. The values for island arc basalts are from Brounce et al. (2014), Kelley and Cottrell (2012), Kelley and Cottrell (2009).The circle marked "a" is the highest $\mathrm{Fe}^{3+} / \sum \mathrm{Fe}$ measured via XANES in an island arc basaltic glass, and is a single measurement from Augustine volcano (Kelley and Cottrell (2009). The circle marked "b" is the average of the least degassed compositions from the Mariana arc (Brounce et al. 2014). Panel b: This is constructed after Pichavant et al. (2016), with olivine-liquid equilibrium constraints from Burgisser and Bachèlery (2009), bulk rock $\mathrm{FeO}$ and $\mathrm{Fe}_{2} \mathrm{O}_{3}$ analyses from Burgisser et al. (2015), and olivine-spinel equilibria from Burgisser et al. (2015) and Bureau et al (1998b). The solid black line demonstrates the likely $f \mathrm{O}_{2}$ of Reunion magmas during petrogenesis summarized by Pichavant et al. (2016). The pink box marked "this study" shows the $\mathrm{fO}_{2}$ of least degassed magmas inferred here from XANES analyses of melt inclusions

Icelandic magmas have radiogenic isotopic ratios indicating the presence in their source regions of a component characteristic of the "depleted" mantle sources of MORB (DMM; Stracke 2012) plus a "less depleted" component present in many OIB lavas variously referred to as "C", FOZO, and/or PREMA (Hanan and Graham 1996; Hart et al. 1992; Hauri et al. 1994; Stracke 2012; Stracke et al. 2005; Zindler and Hart 1986). Also inferred to be present in the sources of Hawaiian and Icelandic OIBs (Stracke 2012) are variable amounts of isotopically distinct (and also relatively "enriched") mantle components with high ${ }^{87} \mathrm{Sr} /{ }^{86} \mathrm{Sr}$ but low to moderate ${ }^{206} \mathrm{~Pb} /{ }^{208} \mathrm{~Pb}$ (labeled EM1 and EM2; Fig. 2). Figure 2 also shows that magmas from the Canary Islands and Mount Erebus have isotopic characteristics suggesting mixtures of DMM and C/FOZO/PREMA in their mantle sources, plus variable amounts of another component that is absent in Hawaiian and Icelandic magmas, characterized by distinctive radiogenic $\mathrm{Pb}$ isotope ratios (HIMU; Sims et al. 2008; Stracke 2012). 

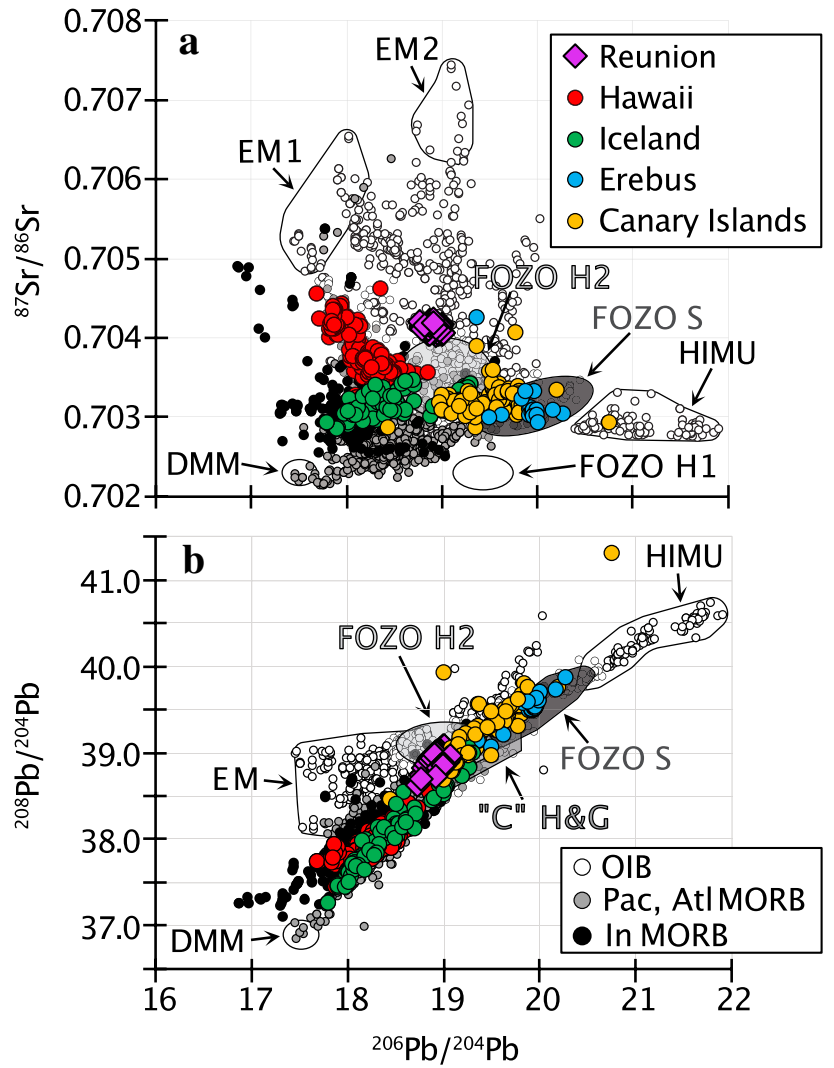

Fig. 2 Plots of radiogenic isotopic compositions of oceanic basalts (gray circles: Paciifc and Atlantic MORB; black circles: Indian MORB; yellow, blue, green, red circles: OIB studied via XANES; white circles: other OIB; pink diamonds: Reunion) from the compilation of Stracke et al. (2005), with Erebus isotopic compositions from Sims et al. (2008). The approximate estimates of the isotopic compositions of various proposed mantle components are marked. The proposed ranges of FOZO/PREMA/C are marked according to reference: FOZO H1 (Hart et al. 1992), FOZO H2 (Hauri et al. 1994), FOZO S (Stracke et al. 2005), "C" H\&G (Hanan and Graham, 1996). a ${ }^{87} \mathrm{Sr} /{ }^{86} \mathrm{Sr}$ versus ${ }^{206} \mathrm{~Pb} /{ }^{204} \mathrm{~Pb}$ and $\mathbf{b}{ }^{208} \mathrm{~Pb} /{ }^{204} \mathrm{~Pb}$ versus ${ }^{206} \mathrm{~Pb} /{ }^{204} \mathrm{~Pb}$

Although definitive links between each isotopic component and specific mantle source lithologies and their provenance are debated, it has been suggested that the EM1, EM2, and HIMU components reflect seafloor sediments, ancient oceanic and/or continental crust and/or lithospheric mantle, and perhaps surface lithologies not currently present at Earth's surface, recycled into the mantle by subduction and subsequently entrained into mantle plumes (e.g., Boyet et al. 2019; Chauvel et al. 1992; Cordier et al. 2021; Garapic et al. 2015; Hofmann and White 1982; Stracke et al. 2005; Zindler and Hart 1986). The origin of the C/FOZO/PREMA component is less certain than those of the other end members, but it has been variously suggested that (1) it may represent portions of the mantle that many plumes interact with to some degree, located in either the transition zone or the lowermost mantle (Hanan and Graham 1996; Hart et al. 1992; Hauri et al. 1994; Giuliani et al. 2021); (2) it may be present or mixed into the mantle sources of MORB (Stracke et al. 2005); (3) perhaps like the EM1, EM2, and HIMU components, it contains recycled oceanic crust or lithosphere (Castillo et al. 2015; Hanan and Graham 1996; Stracke et al. 2005), and/or (4) it may sample a longlived mantle component formed by the extraction of melt from a chondritic mantle that contributed to the continental crust (Giuliani et al. 2021). Whatever the ultimate origin of the isotopic fingerprints associated with these mantle end members, the elevated $\mathrm{Fe}^{3+} / \sum \mathrm{Fe}$ ratios relative to MORBs of the least degassed glasses at Iceland, Hawaii, the Canaries, and Mount Erebus have led to the suggestion that the mantle components that contribute the EM1, EM2, and HIMU isotopic characteristics to their magmas may also contribute oxidized signatures, perhaps acquired during exposure of these components to oxygen- and/or $\mathrm{H}_{2} \mathrm{O}$-rich conditions at Earth's surface prior to recycling into the mantle (Brounce et al. 2017; Moussallam 2016, 2019; Shorttle et al. 2015; Stolper and Keller 2018).

The Reunion hotspot, with its two volcanoes, Piton de la Fournaise and Piton des Neiges, is relatively isotopically homogeneous compared to the OIB discussed above: Basalts from both volcanoes have high ${ }^{208} \mathrm{~Pb} /{ }^{204} \mathrm{~Pb}$ and ${ }^{207} \mathrm{~Pb} /{ }^{204} \mathrm{~Pb}$ at a given ${ }^{206} \mathrm{~Pb} /{ }^{204} \mathrm{~Pb}$; these characteristics define the so-called DUPAL anomaly (Fig. 2b; Dupré and Allègre 1983; Hart 1984) that are shared among OIB and MORB lavas erupted in the Indian Ocean. Taken together, the Pb, $\mathrm{Sr}$ (Fig. 2), Nd, and $\mathrm{Hf}$ isotopic ratios of Reunion lavas have been used to suggest a dominance of C/FOZO/PREMA in the mantle sources of Reunion lavas ( $>90 \%$ ), with only minor contributions from EM1 (reflected in the DUPAL characteristic of these lavas) and even smaller contributions from DMM (Bosch et al. 2008). The Reunion lavas also have chondritic $\mathrm{Th} / \mathrm{U}$ (Vlastélic et al. 2006) and unradiogenic ${ }^{187} \mathrm{Os} /{ }^{188} \mathrm{Os}$ isotopic ratios (Schiano et al. 2012), suggesting that their mantle sources contain an ancient, slightly trace-elementdepleted mantle source that has been minimally influenced by the recycling processes of plate tectonics (Hart 1984; Schiano et al. 2012; Vlastélic et al. 2006; Jackson et al. 2020). Thus, Reunion lavas present the opportunity to study in concentrated form the $f \mathrm{O}_{2}$ of $\mathrm{C} / \mathrm{FOZO} / \mathrm{PREMA}$ without significant complications from recycling of the EM1, EM2, and HIMU mantle components, all of which have been inferrred to contain such recycled and potentially oxidized surface-derived components.

We present here measurements of the major and volatile $\left(\mathrm{H}_{2} \mathrm{O}, \mathrm{S}\right)$ element concentrations and $\mathrm{Fe}^{3+} / \sum \mathrm{Fe}$ ratios of naturally glassy melt inclusions from the 2005 eruption of Piton de la Fournaise on Reunion island and use the results to infer $f \mathrm{O}_{2}$ values of undegassed magmas and of the mantle source of this eruption. We use this $f \mathrm{O}_{2}$, in combination with previously reported $f \mathrm{O}_{2}$ constraints for Reunion island (summarized in Fig. 1b, based on Pichavant et al. 2016), to characterize explicitly the $f \mathrm{O}_{2}$ of the widespread C/FOZO/ PREMA mantle component and compare it to $f_{2}$ levels 
that have been inferred for other distinguishable mantle components.

\section{Sample description}

The samples studied here are from the 2005 eruption of picritic lava flows in the Enclos Fouqué of Piton de la Fournaise volcano, Reunion Island. Large ( $>1 \mathrm{~mm}$ ) olivine grains sampled shortly after eruption were provided for this study by Pascal Richet (IPGP). These samples are similar to those described by Famin et al. (2009). The olivine grains examined in this study contain spherical-to-ovoid naturally glassy melt inclusions ranging in size from $\sim 20 \mu \mathrm{m}$ to $\sim 150 \mu \mathrm{m}$ in diameter, but because of analytical constraints of the Fe-XANES measurements, melt inclusions analyzed here are all $>100 \mu \mathrm{m}$ in diameter. Most melt inclusions contain vapor bubbles, and some contain spinel crystals and sulfide blebs, though the specific melt inclusions analyzed here do not contain spinels or sulfide blebs. Spinels and sulfides are also present as mineral inclusions (i.e., without significant glass; 10-20 $\mu \mathrm{m}$ in diameter) in the olivine crystals, consistent with their having been present at the time of melt inclusion entrapment and not entirely crystallized from the melt inclusions after entrapment. The olivine grains also contain occasional melt embayments $\sim 20 \mu \mathrm{m}$ wide and 100-200$\mu \mathrm{m}$ long that do not contain vapor bubbles. Representative photomicrographs and backscattered electron images of the samples are available in supplementary data Tables 1, 2, 3 .

\section{Methods}

Abundances of major elements, $\mathrm{S}$, and $\mathrm{Cl}$ in the melt inclusions and major elements in the olivines were measured using the JEOL JXA-8200 electron microprobe at the California Institute of Technology. Dissolved $\mathrm{H}_{2} \mathrm{O}$ and $\mathrm{CO}_{2}$ contents in studied glasses were measured via transmission FTIR at the University of California Riverside on a Thermo-Nicolet iS50 spectrometer coupled with a Continuum microscope. We measured $\mathrm{Fe}^{3+} / \sum \mathrm{Fe}$ via $\mathrm{Fe}-\mu$-X-ray absorption near edge structure (XANES) spectroscopy at the Advanced Photon Source, Argonne National Laboratory, beamline 13-IDE following collection procedures described by Brounce et al. (2017). Data are reported in Table 1. Analytical details can be found in the supplementary materials and representative pre-edge spectra are shown in Fig. 3.

\section{Results and discussion}

\section{Major and minor element compositions of melt inclusions and embayments}

The fourteen melt inclusions analyzed in this study are hosted by olivines with compositions ranging from $\mathrm{Fo}_{82}$ to $\mathrm{Fo}_{84}$. To correct the glass analyses for post-entrapment crystallization on the inclusion walls, values from Table 1 were corrected assuming $\mathrm{Fe}^{2+} / \mathrm{Mg} \mathrm{K}_{\mathrm{D}}{ }^{\mathrm{ol} / \mathrm{liq}}=0.3$ (Roeder and Emslie 1970). We added olivine with a composition in equilibrium with the melt inclusion back to the melt in $0.1 \mathrm{wt} \%$ increments until the melt inclusion reached a composition in equilibrium with the host olivine. The amount of olivine added back to the melt inclusions by this correction ranged from 0 to $8.5 \mathrm{wt} \%$, and the corrected melt inclusion compositions contain 6.3-8.5 wt $\% \mathrm{MgO}$ (Table 1). These $\mathrm{MgO}$ contents (and corrected major element compositions more broadly; Fig. 4) are comparable to those obtained by Famin et al. (2009) on glass melt inclusions from the same lava flow using a similar approach and to other melt inclusions from picritic lavas sampled from older eruptions of Piton de la Fournaise (Bureau et al. 1998a, b). We also analyzed three glass embayments partially enclosed by olivines that contain melt inclusions (Reunion-3, Reunion-9, and Reunion-15). These embayment compositions, uncorrected for post-entrapment olivine crystallization, contain 4.9-6.1 wt\% $\mathrm{MgO}$.

The $\mathrm{H}_{2} \mathrm{O}$ contents of the studied melt inclusions range from 0.2 to $0.7 \mathrm{wt} \%$, accompanied by a smaller range in $\mathrm{K}_{2} \mathrm{O}$ ( 0.6-0.8 wt\%; Fig. 4f). This would be consistent with $\mathrm{H}_{2} \mathrm{O}$ degassing accompanied by minimal crystallization before or during melt inclusion entrapment in host olivine or diffusive loss of $\mathrm{H}_{2} \mathrm{O}$ from inclusions after entrapment (Le Voyer et al. 2014; Newcombe et al. 2020; Bucholz et al. 2013). As mentioned previously, sulfide blebs are present in some glass inclusions in the same samples (though not in the exact melt inclusions measured here) and as larger inclusions in the host olivines. Sulfur abundances in the glass inclusions are uncorrelated with $\mathrm{H}_{2} \mathrm{O}$ abundances (Fig. 6a), and-although at best weakly correlated with $\mathrm{FeO}^{*}$ (total $\mathrm{Fe}$ as $\mathrm{FeO}$ ) - they are consistent with saturation with molten Fe-rich sulfide (Fig. 5a). Overall, these trends, combined with petrographic observation of sulfide blebs, suggest entrapment as melt inclusions of liquids that were saturated with a sulfide liquid and that $\mathrm{S}$ degassing was minimal during or prior to the time of entrapment. However, the $\mathrm{S}$ concentrations of the embayments are significantly lower than those of the melt inclusions (71-113 ppm in embayments; 858-1244 ppm in the melt inclusions; Fig. 5a), and $\mathrm{H}_{2} \mathrm{O}$ concentrations in the embayments were below the FTIR detection limit (which we estimate here to be $\sim 0.08 \mathrm{wt} \% \mathrm{H}_{2} \mathrm{O}$ for a doubly 


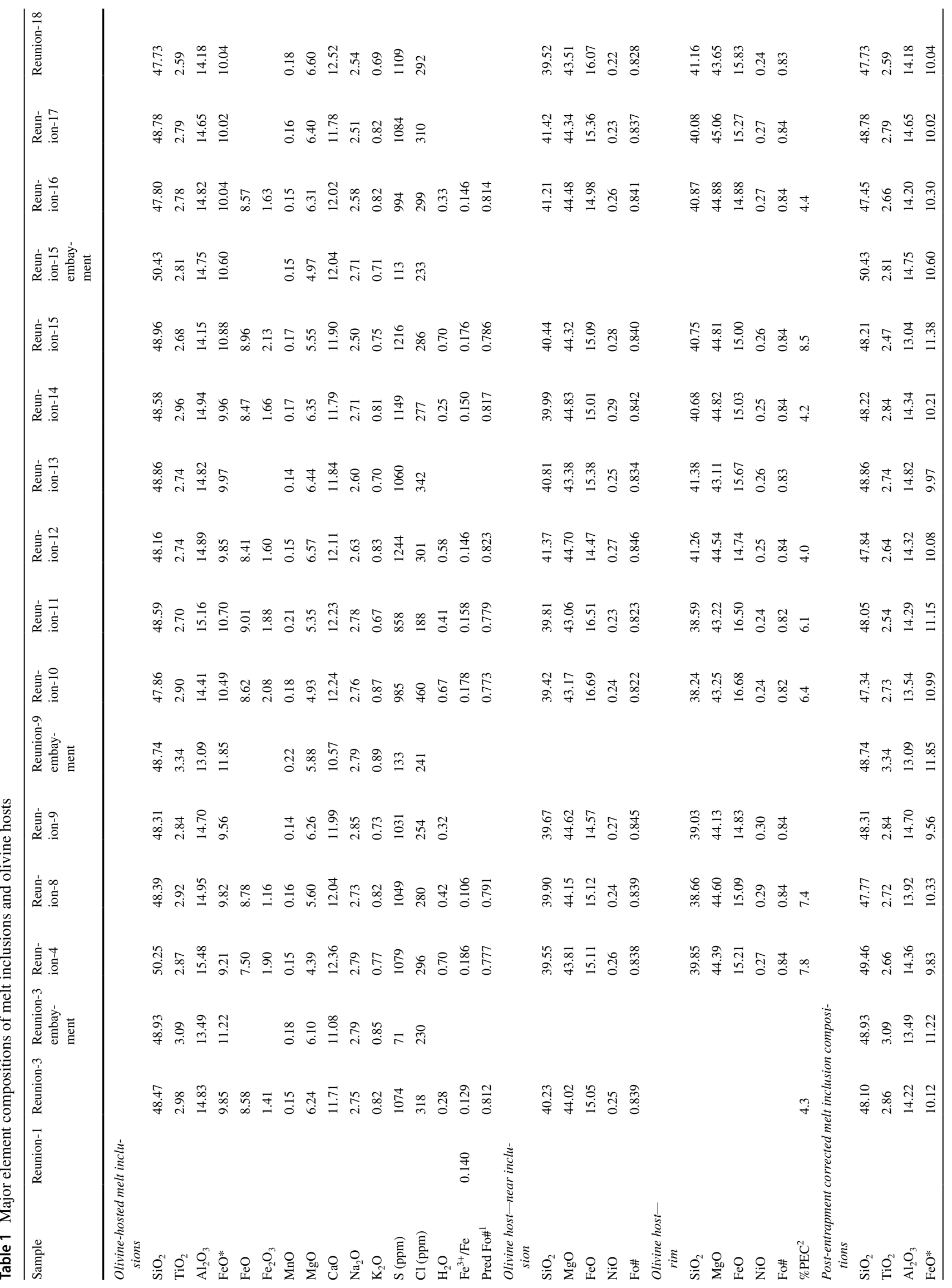




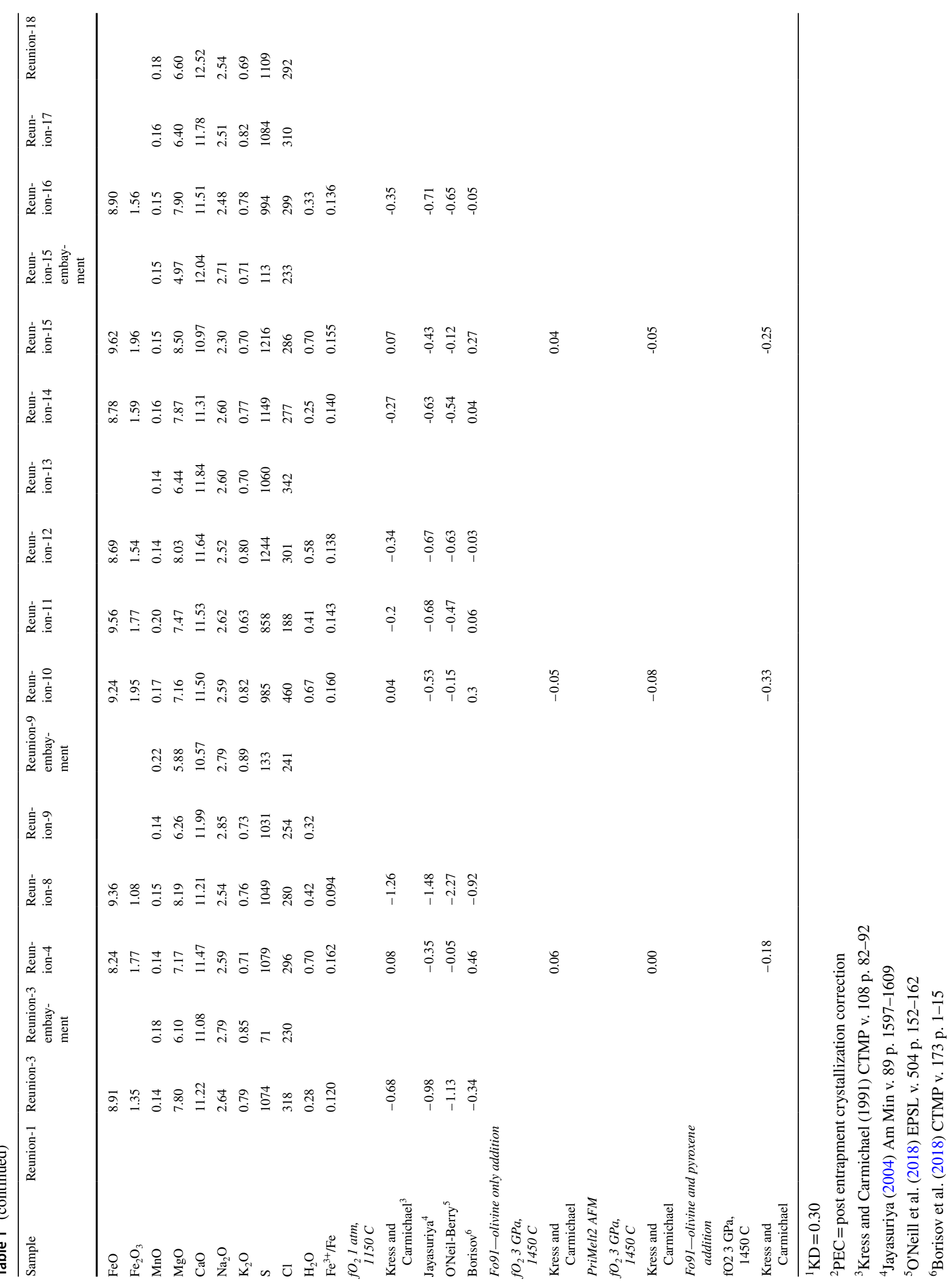



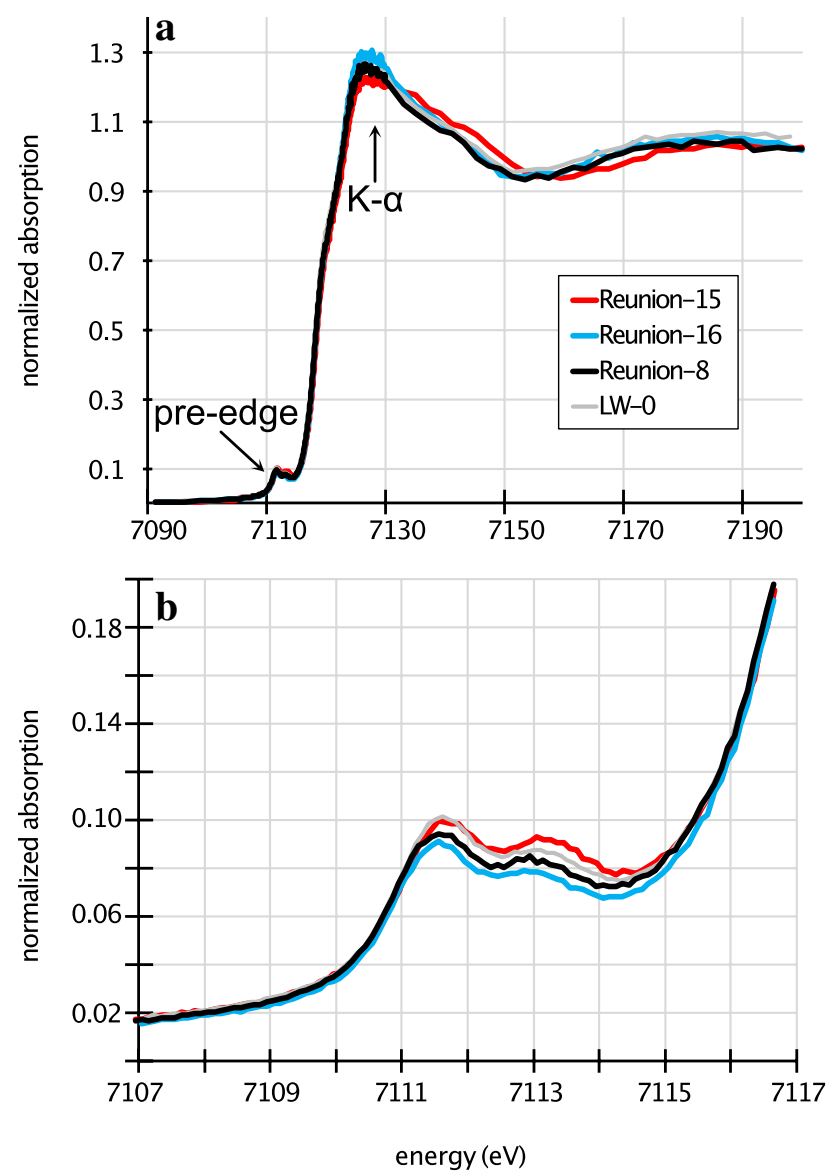

Fig. 3 Plots showing examples of edge-step normalized Fe-XANES spectra from three Reunion melt inclusions $(8,15$, and 16) and the 1-atm gas mixing furnace standard glass LW-0 of ref. 4. Panel (a) shows background, pre-edge, and edge regions, panel (b) magnifies the pre-edge region

polished, $\sim 40 \mu \mathrm{m}$ thick wafer based on the limit below which it begins to be difficult to confidently distinguish signal from noise in IR spectra; Fig. 4e, f). The significant depletion of both $\mathrm{H}_{2} \mathrm{O}$ and $\mathrm{S}$ in the melt embayments relative to the melt inclusions indicates that, in contrast to the melt inclusions, the melt in the embayments degassed nearly to completion upon and/or prior to eruption and emplacement of the lava flow on the surface.

\section{$\mathrm{Fe}^{3+} / \Sigma \mathrm{Fe}$ ratios}

The $\mathrm{Fe}^{3+} / \sum \mathrm{Fe}$ ratios of glass in nine melt inclusions range from 0.094 to 0.162 , a range greater than expected based only on the reproducibility of XANES measurements $( \pm 0.01$, e.g., Cottrell and Kelley 2009). The $\mathrm{Fe}^{3+} / \sum \mathrm{Fe}$ ratios of Reunion melt inclusions are uncorrelated with $S$ contents (Figs. 5b, 6b), in contrast with previous XANES measurements of $\mathrm{Fe}^{3+} / \sum \mathrm{Fe}$ and $\mathrm{S}$ in OIB submarine glasses (see Sect. 1 above, and Brounce et al.
2017; Hartley et al. 2017; Helz et al. 2017; Moussallam et al. 2014, 2016, 2019; Shorttle et al. 2015; Novella et al. 2020). The Reunion glasses are also lower in $\mathrm{Fe}^{3+} / \sum \mathrm{Fe}$ value than XANES-based measurements of other undegassed OIB glasses (Fig. 1a; $0.17-0.40 \mathrm{Fe}^{3+} / \sum \mathrm{Fe}$ ). There is, however, a weak correlation between $\mathrm{Fe}^{3+} / \sum \mathrm{Fe}$ and $\mathrm{H}_{2} \mathrm{O}$ contents for Reunion glasses (Fig. 6c) and we consider three processes that might account for this correlation and the observed $\mathrm{Fe}^{3+} / \sum \mathrm{Fe}$ range more generally.

\section{Degassing}

Degassing of S-rich gases is known to lead to a decrease in the $\mathrm{Fe}^{3+} / \sum \mathrm{Fe}$ ratio of residual liquid under most conditions (Anderson and Wright 1972; Brounce et al. 2017; Burgisser and Scaillet, 2007; Candela 1986; Carmichael and Ghiorso 1986; Gaillard 2011, 2015; Hartley et al. 2017; Helz et al. 2017; Kelley and Cottrell 2012; Metrich et al. 2009; Moussallam et al. 2014, 2016, 2019; Shorttle et al. 2015). One possible explanation of our findings for Reunion glasses is that $\mathrm{S}$ degassing prior to or synchronous with inclusion entrapment (or even afterwards by degassing into vapor bubbles in the inclusions) generated the $\mathrm{Fe}^{3+} / \sum \mathrm{Fe}$ variations we have observed. Although the inclusions we have studied do not appear to have undergone significant amounts of S loss by degassing (e.g., the lowest concentrations are in excess of $850 \mathrm{ppm} \mathrm{S}$ ) and we observe no strong relationship between $\mathrm{S}$ and $\mathrm{Fe}^{3+} / \sum \mathrm{Fe}$ (Figs. 5b, 6b), they do display a range in $\mathrm{S}$ contents ( $\sim 850-1250 \mathrm{ppm})$. Additionally, melt inclusions from prior eruptions at Piton de la Fournaise extend the range of observed S contents significantly $(\sim 550-1760 \mathrm{ppm}$; Bureau et al. 1998a; Fig. 5a). Even though the inclusions studied here have $\mathrm{Fe}^{3+} / \sum \mathrm{Fe}$ ratios that are uncorrelated with $\mathrm{S}$ content (Fig. 6b), we can estimate the expected range in $\mathrm{Fe}^{3+} / \sum \mathrm{Fe}$ ratio that would arise by degassing alone using the D-COMPRESS model of Burgisser et al. (2015). According to this model, degassing to a final pressure of 1 bar of an initial melt with $\mathrm{Fe}^{3+} / \sum \mathrm{Fe}=0.16,0.67 \mathrm{wt} \% \mathrm{H}_{2} \mathrm{O}, 1200 \mathrm{ppm}$ $\mathrm{S}$, and $200 \mathrm{ppm} \mathrm{CO}_{2}$ (i.e., values consistent with this study and $\mathrm{CO}_{2}$ reported by Famin et al. 2009, both studies of melt inclusions from the same eruption) results in a decrease of $\mathrm{Fe}^{3+} / \sum \mathrm{Fe}$ ratio to 0.12 . However, if the predictions of the D-COMPRESS model are accurate (and it is possible that it provides a minimum estimate of the impact of $\mathrm{S}$ degassing on redox, because it assumes that oxidized $\mathrm{S}$ is speciated in the melt as $\mathrm{SO}_{2}$ rather than $\mathrm{SO}_{4}{ }^{2-}$ ), neither closed nor open system degassing describes well the observed change in $\mathrm{Fe}^{3+} / \sum \mathrm{Fe}$ with decreasing $\mathrm{H}_{2} \mathrm{O}$ contents (black solid and dashed curves, Fig. $6 \mathrm{c}$ ) or the lack of a correlation between $\mathrm{S}$ content and $\mathrm{Fe}^{3+} / \sum \mathrm{Fe}$ ratio (Fig. 6b) in the melt inclusion suite measured here. We thus conclude that although degassing may have influenced the melt inclusions we have 
Fig. 4 Plots of major element compositions and $\mathrm{H}_{2} \mathrm{O}$ contents of olivine-hosted melt inclusions and glassy embayments studied here, compared to reported compositions of olivine-hosted melt inclusions from the same eruption (green circles; Famin et al. 2009), and from older eruptions of the same volcano (yellow circles, Bureau et al. 1998a, b), and SWIR MORB (Birner et al. 2018). a $\mathrm{CaO}$ and $\mathrm{MgO}$, b FeO* and $\mathrm{MgO}, \mathbf{c ~} \mathrm{Al}_{2} \mathrm{O}_{3}$ and $\mathrm{MgO}$, d $\mathrm{TiO}_{2}$ and $\mathrm{MgO}$, e $\mathrm{H}_{2} \mathrm{O}$ and $\mathrm{MgO}$, and $\mathbf{f} \mathrm{H}_{2} \mathrm{O}$ and $\mathrm{K}_{2} \mathrm{O}$
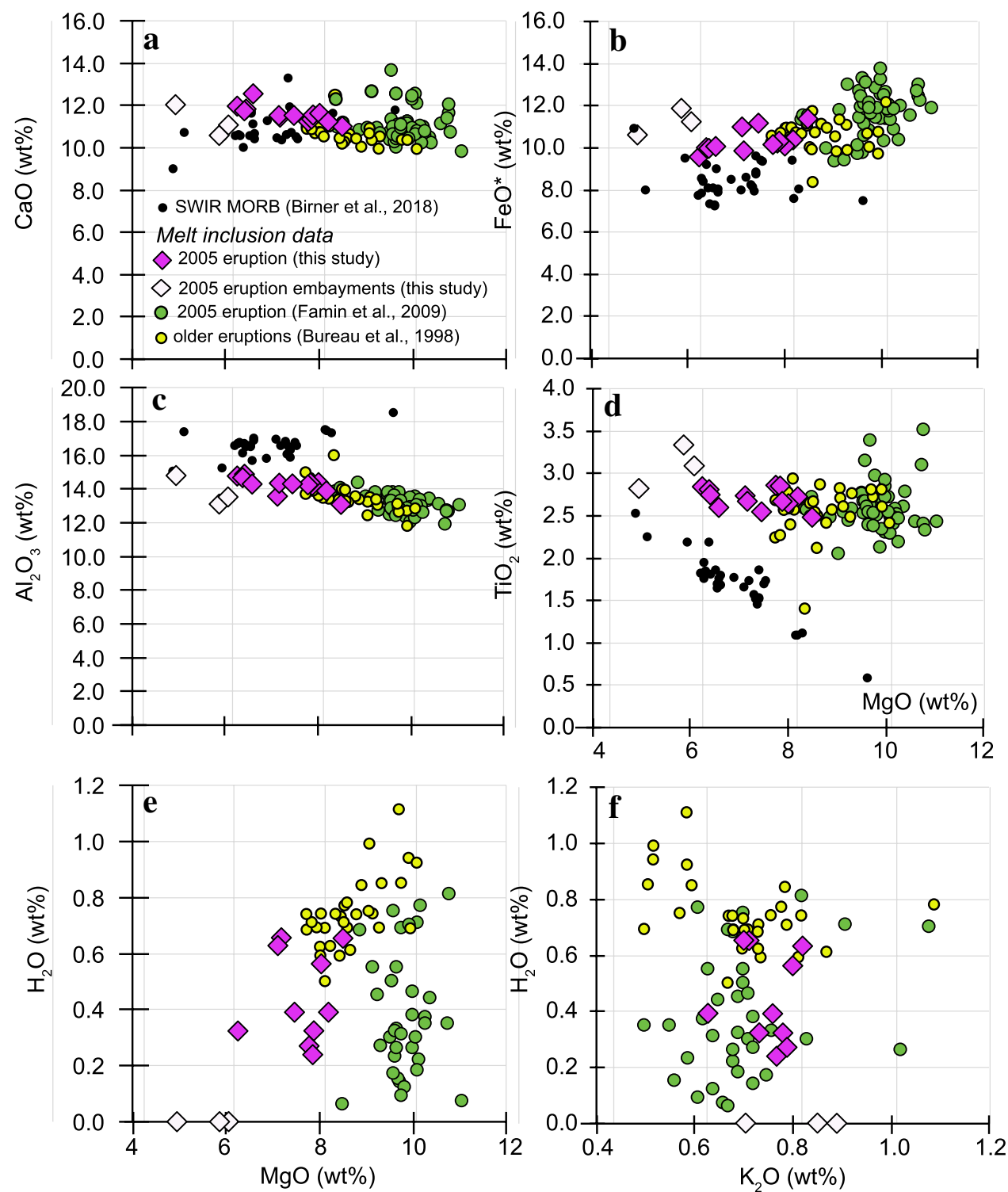

studied, to the degree that the D-COMPRESS model accurately captures the effects of degassing on depressurization, such a process cannot simply explain the observed variations in $\mathrm{Fe}^{3+} / \sum \mathrm{Fe}$ (but see Sect. 4.2.3 for an alternate degassing process that for the most part matches our observations).

Previous studies of melt inclusions from older eruptions of Piton de la Fournaise have measured $\mathrm{H}_{2} \mathrm{O}$ contents as high as $1.1 \mathrm{wt} \%$ and $\mathrm{S}$ contents as high as $1760 \mathrm{ppm} \mathrm{S}$ (Bureau et al. 1998a, b; Fig. 5a, 6). Additionally, measurements of fluid inclusions indicate very high $\mathrm{CO}_{2}$ contents of deeply stored magmas at Piton de la Fournaise (e.g., $>1$ wt $\% \mathrm{CO}_{2}$; Boudoire et al. 2018). This raises the possibility that the liquids trapped in the melt inclusions studied here evolved by degassing prior to entrapment from liquids that contained higher initial concentrations of $\mathrm{CO}_{2}, \mathrm{H}_{2} \mathrm{O}$ and $\mathrm{S}$ than observed by us in any of the melt inclusions we have studied. Using D-COMPRESS, we have estimated the range of possible initial values of $\mathrm{Fe}^{3+} / \sum \mathrm{Fe}$ ratios that would be required to explain partially degassed compositions equivalent to melt inclusions studied here (gray star and connected curves, Fig. 6) and conclude that undegassed magmas with $1.1 \mathrm{wt} \% \mathrm{H}_{2} \mathrm{O}, 200 \mathrm{ppm} \mathrm{CO}_{2}$, and $1700 \mathrm{ppm} \mathrm{S}$ could have $\mathrm{Fe}^{3+} / \sum \mathrm{Fe}$ ratios no higher than $0.15-0.17$ to degas to a $\mathrm{Fe}^{3+} / \sum \mathrm{Fe}$ ratio of 0.12 and $\sim 700 \mathrm{ppm} \mathrm{S}$ (gray star and associated black curves, Fig. 6b, c).

\section{Temperature dependence of homogeneous equilibrium between $\mathrm{Fe}$ and $\mathrm{S}$ in melt}

Another possibility that might in principle account for the range in observed $\mathrm{Fe}^{3+} / \sum \mathrm{Fe}$ ratios in the centers of Reunion melt inclusions is that this ratio increases during cooling and 


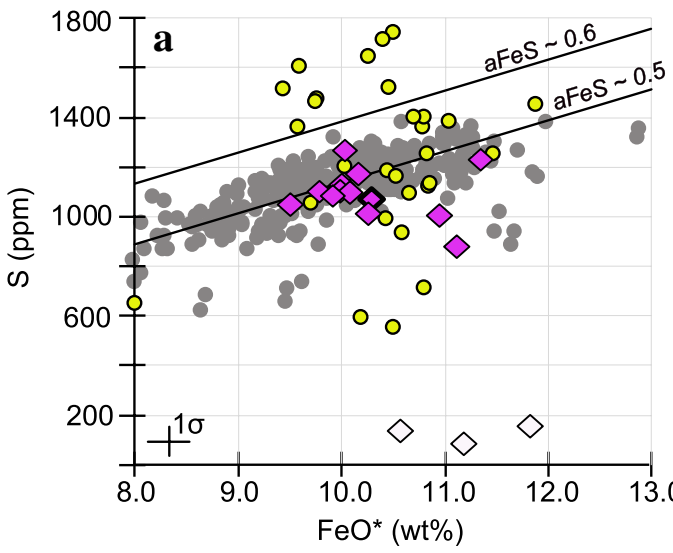

2005 picrite eruption Piton de la Fournaise

$\diamond$ melt inclusions (post-entrapment corrected)

- melt inclusions (post-entrapment uncorrected)

$\diamond$ embayments

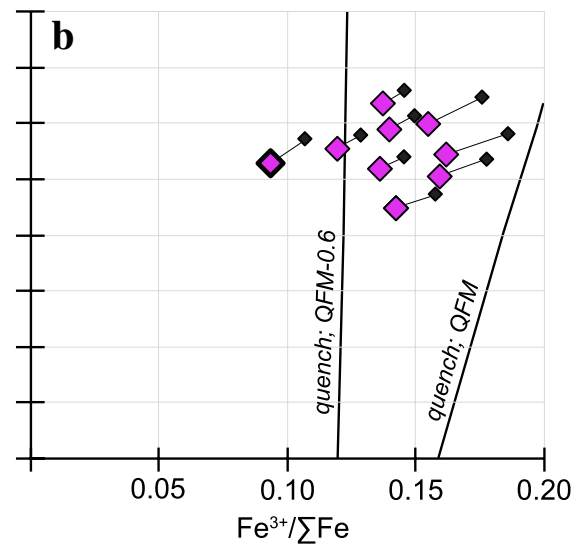

Other Piton de la Fournaise eruptions

o melt inclusions

Bureau et al., 1998

- MORB, Jenner et al., 2012
Fig. 5 a $\mathrm{S}$ and $\mathrm{FeO}^{*}$ concentrations of olivine-hosted melt inclusions and glassy embayments. Small gray circles are MORB glasses (Jenner and O'Neill, 2012). Black lines show the calculated S content of silicate melt at sulfide saturation according to the model of O'Neill and Mavrogenes (2002) setting $a \mathrm{FeS}$ equal to 0.5 and 0.6 , as indicated. Yellow circles are measurements of olivine-hosted melt inclusions from older eruptions of Piton de la Fournaise volcano (Bureau et al. 1998a, b). b Plot of $\mathrm{S}$ concentrations and $\mathrm{Fe}^{3+} / \sum \mathrm{Fe}$ ratios. Small black diamonds are measured values, uncorrected for the

quenching of the melt inclusion to glass, because the electron transfer reaction $8 \mathrm{Fe}^{2+}+\mathrm{S}^{6+}=8 \mathrm{Fe}^{3+}+\mathrm{S}^{2-}$ is driven to the right with decreasing temperature (Nash et al. 2019). A key prediction of this hypothesis is that the higher the $\mathrm{S}^{6+}$ content of the high-temperature melt, the more effective this mechanism is at increasing $\mathrm{Fe}^{3+} / \sum \mathrm{Fe}$ ratio for a given $\mathrm{FeO}^{*}$ and initial $\mathrm{Fe}^{3+} / \sum \mathrm{Fe}$. Assuming an initial $f \mathrm{O}_{2}$ of QFM-0.6 (calculated $\mathrm{Fe}^{3+} / \sum \mathrm{Fe}=0.120$ for a glass with the major element composition of Reunion-3 from Kress and Carmichael 1991), $10 \mathrm{wt} . \% \mathrm{FeO}^{*}$, total $\mathrm{S}$ contents ranging from 850 to $1250 \mathrm{ppm}$, and that cooling begins from $1160{ }^{\circ} \mathrm{C}$ (the estimated liquidus temperature of the melt in the center of a typical melt inclusion according to the $\mathrm{MgO}$ thermometer of Helz and Thornber 1987), we calculate that the $\mathrm{Fe}^{3+} / \sum \mathrm{Fe}$ ratio would increase on quenching from 0.120 to 0.122 at $850 \mathrm{ppm} \mathrm{S}$ and from 0.120 to 0.126 at $1250 \mathrm{ppm}$ $\mathrm{S}$ (Fig. 5b). This range of quenched $\mathrm{Fe}^{3+} / \sum \mathrm{Fe}$ ratios is significantly smaller than the range observed in the Reunion melt inclusions. This - and the fact that there is no observed correlation between total $\mathrm{S}$ content and $\mathrm{Fe}^{3+} / \sum \mathrm{Fe}$ ratio for these inclusions (Fig. 5b) - argue against this mechanism contributing significantly to the observed range of $\mathrm{Fe}^{3+} / \sum \mathrm{Fe}$ ratio. effects of post-entrapment olivine crystallization on the melt inclusion wall. Pink diamonds are the compositions after correction for post-entrapment crystallization (PEC) of olivine on the melt inclusion wall. Thin black lines connect the pre-PEC and post-PEC compositions of the same inclusions. Thick black lines show the proposed effect of Fe-S redox coupling during quench as a function of the $\mathrm{S}$ content of a melt at $\Delta \mathrm{QFM} \sim 0$ and $\Delta \mathrm{QFM}-0.6$ according to Nash et al. (2019)

\section{Post-entrapment diffusion through the enclosing olivine}

The final possibility that we consider is that the variation in measured $\mathrm{Fe}^{3+} / \sum \mathrm{Fe}$ ratios of the Reunion melt inclusions reflects post-entrapment diffusion of metal vacancies across the olivine host in response to a difference in $f \mathrm{O}_{2}$ between the melt inclusion and the host magma. It has been shown that $\mathrm{H}_{2} \mathrm{O}$ contents of olivine-hosted melt inclusions can reequilibrate with the surrounding magma by diffusion of $\mathrm{H}^{+}$across the olivine in $\sim 10 \mathrm{~s}$ of hours and that metal vacancies in the host olivine move at similar rates (Bucholz et al. 2013; Gaetani et al. 2012). Consequently, suites of variably re-equilibrated melt inclusions could record a range of $\mathrm{Fe}^{3+} / \sum \mathrm{Fe}$ ratios and $\mathrm{H}_{2} \mathrm{O}$ concentrations due to varying extents of $\mathrm{H}_{2} \mathrm{O}$ and metal vacancy exchange across the olivine after entrapment (Bucholz et al. 2013; Gaetani et al. 2012). For example, suppose that the Reunion melt inclusions were trapped at pressures higher than those at which significant $\mathrm{H}_{2} \mathrm{O}$ and/or $\mathrm{S}$ degassing occurs; this would be the case if the melt inclusions were trapped at $\sim 800$ bars, the depth of magma storage of Reunion picritic magmas (Famin et al. 2009), since this is higher than the 330 bars at which, according to D-COMPRESS, a model undegassed Reunion liquid begins to degas significant quantities of $\mathrm{H}_{2} \mathrm{O}$. The magma containing the olivine-hosted melt inclusions could then have ascended rapidly to a lower, near-surface pressure, 

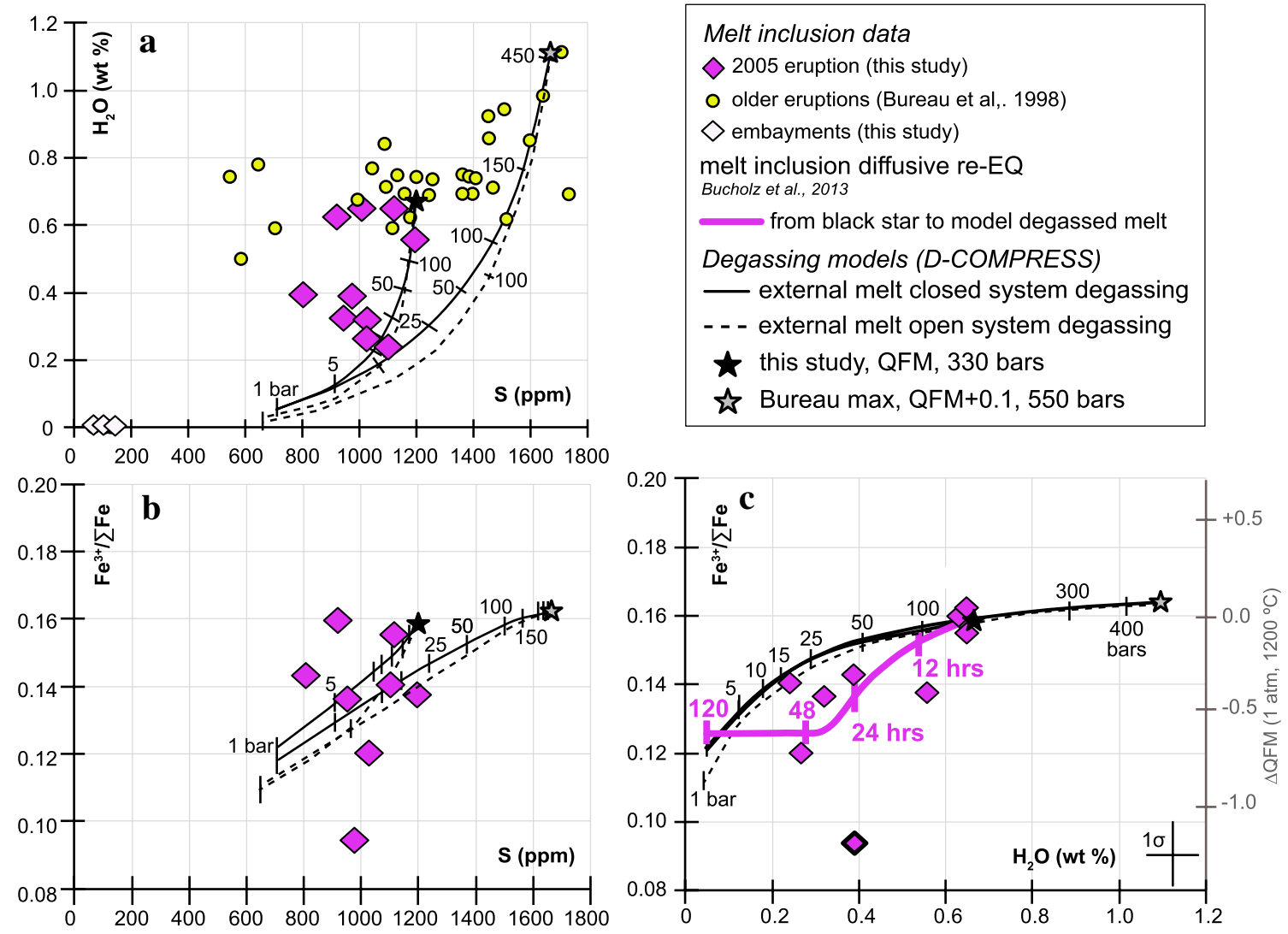

Fig. 6 a $\mathrm{H}_{2} \mathrm{O}$ and $\mathrm{S}$ concentrations of olivine-hosted melt inclusions and glassy embayments. The solid and dashed curves are D-COMPRESS (Burgisser et al. 2015) model trajectories of the expected change in $\mathrm{H}_{2} \mathrm{O}$ and $\mathrm{S}$ during degassing in a closed (solid black curves) and open (black dashed curves) system. The stars mark the starting composition of open and closed system trajectories. Tick marks show the progression of pressure in bars. b Plot of $\mathrm{Fe}^{3+} / \sum \mathrm{Fe}$ ratios and $\mathrm{S}$ concentrations of olivine-hosted melt inclusions, with

at which point the liquid fraction of the magma would have degassed most of its $\mathrm{H}_{2} \mathrm{O}$ and $\mathrm{S}$, resulting in a decrease in $f \mathrm{O}_{2}$ from $\Delta \mathrm{QFM}=0$ to -0.7 . In contrast, a melt inclusion would not have degassed on ascent nearly as extensively into vapor bubbles as would the liquid enclosing its olivine host, because the inclusion would have experienced a significantly smaller decrease in pressure on ascent as it maintained an approximately constant volume. Such a situation would give rise to a low $\mathrm{H}_{2} \mathrm{O}, \mathrm{S}$, and $f \mathrm{O}_{2}$ liquid outside the olivine and a higher $\mathrm{H}_{2} \mathrm{O}, \mathrm{S}$, and $f \mathrm{O}_{2}$ liquid inside the melt inclusion. Because $\mathrm{H}_{2} \mathrm{O}, \mathrm{H}$-bearing defects, and metal vacancies can diffuse across the host olivine, total $\mathrm{H}_{2} \mathrm{O}$ concentration and $\mathrm{fO}_{2}$ in the melt inclusions can change on relatively short time scales, ultimately taking on values near those of the degassed enclosing liquid. In contrast, total $\mathrm{S}$ concentrations in the melt inclusions would be unchanged assuming $\mathrm{S}$ cannot be transported across the host olivine (Bucholz et al. 2013; Gaetani et al. 2012; Newcombe et al. 2014; Rowe et al. 2007; Saper and Stolper 2020).

the same degassing models as in panel a. $\mathbf{c} \mathrm{Fe}^{3+} / \sum \mathrm{Fe}$ ratios and $\mathrm{H}_{2} \mathrm{O}$ concentrations in olivine-hosted melt inclusions. The same degassing trajectories from panels $\mathrm{a}$ and $\mathrm{b}$ are shown. The thick pink curve is the modeled effect of diffusive re-equilibration of $\mathrm{H}_{2} \mathrm{O}$ and $\mathrm{Fe}^{3+} / \sum \mathrm{Fe}$ according to Bucholz et al. (2013), with tick marks indicating time in hours. Approximate $f \mathrm{O}_{2}$ relative to QFM is shown on the left hand $y$-axis, calculated at fixed major element composition. Bolded pink diamond has the lowest $\mathrm{Fe}^{3+} / \sum \mathrm{Fe}$ measured in this study, see text

The range in $\mathrm{H}_{2} \mathrm{O}$ contents and $f \mathrm{O}_{2}$ recorded by Reunion melt inclusions might thus reflect their variable extents of transfer of H-bearing species and metal vacancies across the olivine host, while the $\mathrm{S}$ contents of the inclusions would still largely reflect the undegassed magma originally trapped in the melt inclusions. We simulated this process and the expected changes in $\mathrm{H}_{2} \mathrm{O}$ and $\mathrm{Fe}^{3+} / \sum \mathrm{Fe}$ in an initially hydrous and oxidized melt inclusion that is communicating diffusively with a relatively dry and reduced external magma using the numerical model of Bucholz et al. (2013). We assumed a $150 \mu \mathrm{m}$ diameter spherical melt inclusion enclosed in the center of a $1 \mathrm{~mm}$ diameter olivine at $1100{ }^{\circ} \mathrm{C}$; we also assumed that the melt inclusion initially contained $0.67 \mathrm{wt} \% \mathrm{H}_{2} \mathrm{O}$ at $\mathrm{QFM}\left(\mathrm{Fe}^{3+} / \sum \mathrm{Fe} \sim 0.16\right)$ and that the host melt degassed from this initial composition to $1 \mathrm{bar}$, resulting in $0.05 \mathrm{wt} \% \mathrm{H}_{2} \mathrm{O}$ and an $f \mathrm{O}_{2}$ of QFM-0.7 according to D-COMPRESS (equivalent to $\mathrm{Fe}^{3+} / \sum \mathrm{Fe} \sim 0.120$ ). Using the model from Bucholz et al. (2013), shown by the pink curve in Fig. 6c, a melt inclusion 
would approach equilibrium with the degassed external melt with $0.05 \mathrm{wt} \% \mathrm{H}_{2} \mathrm{O}$ in $\lesssim 200 \mathrm{~h}$, by which point the $\mathrm{H}_{2} \mathrm{O}$ in the melt inclusion would have decreased to 0.05 wt $\%$ and the $\mathrm{Fe}^{3+} / \sum \mathrm{Fe}$ has decreased to $\sim 0.125$ (i.e., to the values of the external melt). The modelled concentration of metal vacancies across the olivine grain becomes nearly homogeneous after $\sim 48 \mathrm{~h}$, at which point the $f \mathrm{O}_{2}$ of the modelled melt inclusion is essentially equal to that of the external melt and little further change in $f_{2}$ (and $\mathrm{Fe}^{3+} / \sum \mathrm{Fe}$ ) in the melt inclusion occurs. At this time, the modelled olivine still has a gradient in $\mathrm{H}^{+}$, and so the $\mathrm{H}_{2} \mathrm{O}$ content of the modelled inclusion continues to decrease at roughly constant $f \mathrm{O}_{2}$; at $200 \mathrm{~h}$, the model $\mathrm{H}_{2} \mathrm{O}$ content has changed $91 \%$ of the way towards the final value of 0.05 wt $\%$.

With the exception of the data point with the lowest $\mathrm{Fe}^{3+} / \sum \mathrm{Fe}$ data point (Reunion-8, shown as the pink diamond outlined in black in Fig. 6c), this diffusion model describes the melt inclusion measurements reasonably well, and most importantly, better than the simple degassing models described in Sect. 4.2.1 based on D-COMPRESS (shown in Fig. $6 \mathrm{c}$ as black solid and dashed curves). Based on the observations of Bucholz et al. (2013) and Gaetani et al. (2012) that ${ }^{1} \mathrm{H}$ diffuses more rapidly through olivine hosts than ${ }^{2} \mathrm{H}$ in experimentally dehydrated olivine-hosted melt inclusions, a prediction of this explanation for the observed correlation between $\mathrm{Fe}^{3+} / \sum \mathrm{Fe}$ and dissolved $\mathrm{H}_{2} \mathrm{O}$ contents of the Reunion melt inclusions is these inclusions will also record a range in $\mathrm{D} / \mathrm{H}$ ratios that vary as a function of progressive diffusive $\mathrm{H}_{2} \mathrm{O}$ loss from the inclusions.

As mentioned above, one melt inclusion with $0.42 \mathrm{wt} \%$ $\mathrm{H}_{2} \mathrm{O}$ (Reunion-8, shown as the pink diamond outlined in black in Figs. 4, 5, 6), has the lowest measured $\mathrm{Fe}^{3+} / \sum \mathrm{Fe}$ (0.094). This sample is indistinguishable from the other inclusions included in this study in its major or volatile element composition, and it is unremarkable petrographically. Although it is always possible that some amount of olivine was included in the analytical volume, skewing the pre-edge spectral features to result in lower calculated $\mathrm{Fe}^{3+} / \sum \mathrm{Fe}$ ratios than glass measurements alone, there is no spectral evidence for such "olivine contamination" elsewhere in the XANES spectrum (see Brounce et al. 2014). Otherwise, we have no testable explanation for this anomalous data point, although it could reflect variations among inclusions in the initial $\mathrm{Fe}^{3+} / \sum \mathrm{Fe}$ of the trapped liquid or equilibration with a more reduced host liquid such that the plateau in the modeled curve in Fig. $6 \mathrm{c}$ would be at a lower $\mathrm{Fe}^{3+} / \sum \mathrm{Fe}$ ratio.

In the context of the model described in this subsection and illustrated in Fig. 6c, the samples with the highest $\mathrm{H}_{2} \mathrm{O}$ and $\mathrm{Fe}^{3+} / \sum \mathrm{Fe}$ ratios (Reunion-4, Reunion-10, and Reunion-15) would be most representative of the $f \mathrm{O}_{2}$ of the least degassed and/or the least re-equilibrated Reunion liquids sampled in melt inclusions. These samples have average $\mathrm{Fe}^{3+} / \sum \mathrm{Fe}=0.158 \pm 0.005, \mathrm{H}_{2} \mathrm{O}=0.69 \pm 0.02$, and $\mathrm{S}=1090 \pm 110 \mathrm{ppm}$ (Table 1), corresponding to an $f \mathrm{O}_{2}$ of $\Delta \mathrm{QFM} \approx 0$, similar to the summary of previous estimates of $f \mathrm{O}_{2}$ for Reunion island lavas shown in Fig. $1 \mathrm{~b}$ (which shows our data, that of Gaborieau et al. 2020, and previous data summarized by Pichavant et al. 2016). It is also similar to the average $f \mathrm{O}_{2}$ reported for MORB in the Indian ocean basin (Birner et al. 2018; Zhang et al. 2018). We emphasize, however, that we cannot rule out that even the liquids trapped in these three inclusions have lost some $\mathrm{CO}_{2}, \mathrm{H}_{2} \mathrm{O}$ and $\mathrm{S}$ prior to entrapment. Although we have no evidence that this occurred, we do note again the higher $\mathrm{H}_{2} \mathrm{O}$ and $\mathrm{S}$ contents of the samples of Bureau et al. 1998a, b from an earlier eruption (Figs. 5a, 6a) and inferences from fluid inclusions of elevated $\mathrm{CO}_{2}$ magmas stored at depth at Piton de la Fournaise. However, modeled degassing trajectories from such a volatile-rich magma show that the effect on $\mathrm{Fe}^{3+} / \sum \mathrm{Fe}$ (and thus on $f \mathrm{O}_{2}$ ) is small-i.e., to reproduce the melt inclusions with $\mathrm{Fe}^{3+} / \sum \mathrm{Fe} \approx 0.158$ with the volatile contents observed here, the undegassed magma could not have had an $f \mathrm{O}_{2}$ not higher than $\Delta \mathrm{QFM} \approx+0.1$.

\section{Oxygen fugacities of Reunion Island and Indian Ocean MORB primary magmas}

We present three approaches to estimating primary melt compositions (i.e., compositions immediately after segregation of primitive melt(s) from mantle residues and prior to crystallization-differentiation and degassing) based on our measurements and estimates (described in the following text) of the possible range of amounts of crystal fractionation prior to melt entrapment in olivine.

We first incrementally added equilibrium liquidus olivine back to the compositions of Reunion-4, Reunion-10, Reunion-15 (see Sect. 4.2.3) until they reached equilibrium with $\mathrm{Fo}_{91}$ olivine (consistent with the estimated olivine in the Reunion residual mantle source; Sobolev and Nikogosian 1994). Calculation of olivine addition was done as described in Sect. 4.1 for the post-entrapment crystallization correction. This required 24-31 wt\% olivine addition and produces model melt compositions with $15.0-16.9 \mathrm{wt} \% \mathrm{MgO}$ and 8.6-9.3 wt\% $\mathrm{CaO}$. The model estimate for $\mathrm{CaO}$ content is lower than expected for batch melts or accumulated fractional melts of a fertile or slightly depleted peridotitic source, suggesting that crystallization of high-Ca pyroxene in addition to olivine occurred prior to melt inclusion entrapment; this inference is consistent with prior studies of the liquid lines of descent of Reunion magmas (e.g., Albarede et al. 1997; Famin et al. 2009). The model primary melts reconstructed in this way have $\Delta \mathrm{QFM}=-0.4$ (calculated at $1 \mathrm{~atm}, 1150{ }^{\circ} \mathrm{C}$ ); this $f \mathrm{O}_{2}$ is $\sim 0.4$ orders of magnitude lower than those calculated from measured $\mathrm{Fe}^{3+} / \sum \mathrm{Fe}$. The representative pressures and temperatures of melting independently estimated 


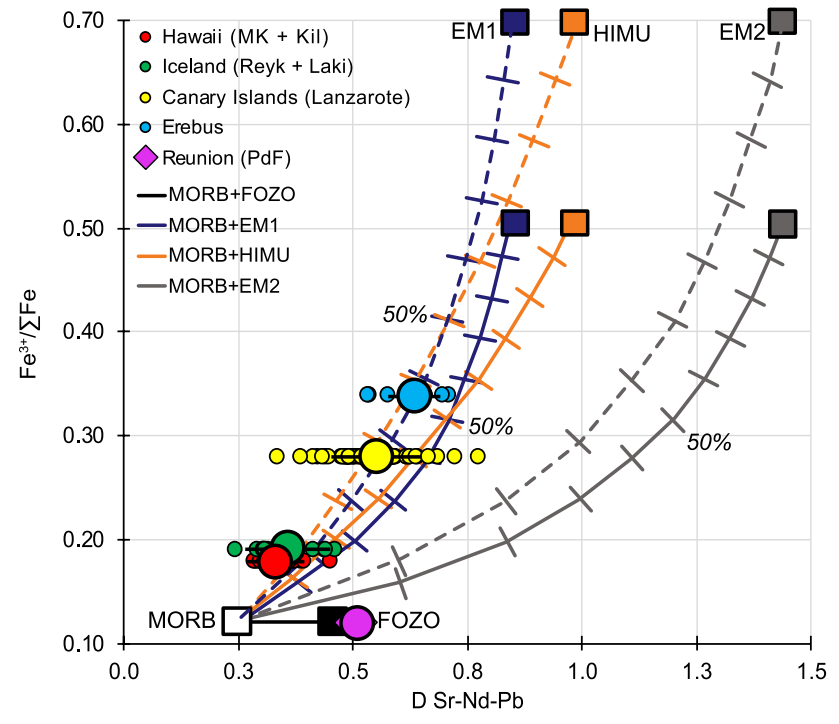

Fig. 7 Plot of the $\mathrm{Fe}^{3+} / \sum \mathrm{Fe}$ ratios of "most parental" magmas (see Fig. 1) versus $\mathrm{D}^{\mathrm{Sr}-\mathrm{Nd}-\mathrm{Pb}}$ of Jackson et al. (2020), an index for the extent of the shift away from geochemically depleted mantle with respect to $\mathrm{Sr}, \mathrm{Nd}$, and $\mathrm{Pb}$ isotopic compositions. The $\mathrm{Fe}^{3+} / \sum \mathrm{Fe}$ ratios of "most parental" magmas at each location are taken from the literature (see Fig. 1), Reunion constraint (this study) described in the main text. Also shown are the calculated $\mathrm{DSr}-\mathrm{Nd}-\mathrm{Pb}$ of melts of DMM, C/FOZO/PREMA, EM1, EM2, and HIMU from Jackson et al. (2020), with various possible $\mathrm{Fe}^{3+} / \sum \mathrm{Fe}$ ratios. The $\mathrm{Fe}^{3+} / \sum \mathrm{Fe}$ ratio of the FOZO component is set equal to that calculated in this study, and MORB is set equal to that of Zhang et al. (2018). The $\mathrm{Fe}^{3+} / \sum \mathrm{Fe}$ ratios of the blue, orange, and gray boxes $(0.5)$ connected to MORB by solid curves is the value measured for the ODP Site 801 Super Composite powder (Brounce et al. 2019), meant to represent the $\mathrm{Fe}^{3+} / \sum \mathrm{Fe}$ of bulk subducting altered oceanic crust and seafloor sediments. The endmembers connected to MORB by dashed curves have $\mathrm{Fe}^{3+} / \sum \mathrm{Fe}$ of 0.7 , illustrating the impact of mixing more oxidized melts on the mixing curve trajectories. Isotopic data for each island from Stracke et al. (2005), Jackson et al. (2020), and Sims et al. (2008)

for Reunion lavas are $3 \mathrm{GPa}$ and $1400{ }^{\circ} \mathrm{C}$ (Albarède et al. 1997; Albarède and Tamagnan 1988; Sobolev and Nikogosian 1994). The effect of increasing temperature from $1150{ }^{\circ} \mathrm{C}$ to $1400{ }^{\circ} \mathrm{C}$ on the calculation of $f \mathrm{O}_{2}$ of a silicate magma relative to the QFM buffer is small $(<0.02 \log$ units at $3 \mathrm{GPa}$; Brounce et al. 2017; Kress and Carmichael, 1991). However, the effect of increasing pressure from 1 atm to 3 GPa increases the $f \mathrm{O}_{2}$ of the silicate liquid by $\sim 0.4$ orders of magnitude relative to the QFM buffer at $1400{ }^{\circ} \mathrm{C}$. The net result of the olivine addition calculations and projection to the high pressures and temperatures of melting nearly cancel one another, yielding an estimate of the $f \mathrm{O}_{2}$ of a Reunion primary melt as it separated from its source of $\Delta \mathrm{QFM} \approx$ $0 \pm 0.1$ (the average and standard deviation of the three values calculated for Reunion-4, Reunion-10, and Reunion-15; Fig. 7; Table 1).

We made a second estimate by adding olivine and clinopyroxene back to the composition of each of the same three melt inclusions until equilibrium with $\mathrm{Fo}_{91}$ olivine was achieved. This calculation was implemented using Petrolog3 (Danyushevsky and Plechov 2011), the mineral-melt models of Roeder and Emslie (1970) for olivine and Langmuir et al. (1992) for high-Ca clinopyroxene, and assuming that $\mathrm{Fe}^{3+}$ is perfectly incomaptible for both olivine and clinopyroxene. Equilibrium olivine and clinopyroxene were added to the compositions of Reunion-4, Reunion-10, and Reunion-15 in proportions dictated by the mineral-melt models cited above until a melt composition in equilibrium with Fo91 olivine was obtained. This required $20-23 \%$ pyroxene and $9-12 \%$ olivine addition using the selected melt models, and produced melt compositions with $13.1-14.7 \mathrm{wt} \% \mathrm{MgO}$ and 12-12.2 wt \% $\mathrm{CaO}$, which are consistent with the range in $\mathrm{MgO}$ and $\mathrm{CaO}$ possible from accumulated fractional melts of a peridotitic source mantle (Herzberg and Asimow 2008). This calculation produces primary melt compositions in equilibrium with $\mathrm{Fo}_{91}$ olivine with average $\Delta \mathrm{QFM}=-0.2 \pm 0.1$ (corrected to 3 $\mathrm{GPa}, 1400{ }^{\circ} \mathrm{C}$, as described for the preceding model calculation; Table 1). Note that using a non-zero value for $\mathrm{D}_{\mathrm{Fe} 3+}{ }^{\mathrm{cpx} /}$ melt (e.g., $~ 0.5$; Sorbadere et al. 2018) would yield a primary magma with slightly higher $f \mathrm{O}_{2}$.

The final calculation was based on the PriMelt2 calculator (Herzberg and Asimow 2008), which is similar to the first calculation presented above except that it simultaneously calculates the composition of accumulated fractional melts of a peridotitic mantle source and thus returns a parental melt composition that is consistent with having been produced by melting of a peridotitic mantle source. This yields modeled primary melt compositions for the Reunion-4, Reunion-10, and Reunion-15 melt inclusion compositions in equilibrium with $\mathrm{Fo}_{91.5}-\mathrm{Fo}_{91.9}$ olivine at $1370-1430{ }^{\circ} \mathrm{C}$ and $3.0 \mathrm{GPa}$, and $\Delta \mathrm{QFM} \approx 0 \pm 0.1$ at the model temperatures and pressures (Table 1). As pointed out above and by Herzberg and Asimow (2008), the PriMelt2 calculations indicate that these reconstructed primary melts have $\mathrm{CaO}$ concentrations that are too low to have segregated from high-Ca pyroxene-bearing residues and, therefore, suggest that significant pyroxene fractionation was involved in producing the melts that were trapped as inclusions analyzed in this study.

These calculations show the insensitivity of estimates of the $f \mathrm{O}_{2}$ values of reasonable primary melts to the precise model choice of how to correct for crystal fractionation. Taken together, the results of these calculations suggest $f \mathrm{O}_{2}$ values for the primary liquid of the 2005 Piton de la Fournaise eruption of $\Delta \mathrm{QFM}=-0.2$ to 0.0 at the point of its separation from the solid residue in its source at approximately 3 $\mathrm{GPa}, 1400^{\circ} \mathrm{C}$. Assuming that the effect of partial melting on the $\mathrm{fO}_{2}$ of the melt and mantle residue is small up to $25 \%$ melting of peridotite (e.g., Sorbadere et al. 2018; Davis and Cottrell 2018); that the melt and residue were in equilibrium and thus reflect the same $f \mathrm{O}_{2}$ up to the point of melt segregation; and that we can approximate melting with a single stage 
of melt extraction), we take this as a reasonable estimate for the $f \mathrm{O}_{2}$ of the mantle sources of Piton de la Fournaise magmas. Estimates of the $f_{2}$ of the Indian upper mantle at the pressures and temperatures of primary melt generation (1.25 $\mathrm{GPa}, 1320^{\circ} \mathrm{C}$; taken directly from Birner et al. 2018), are similar to those for the primitive, undegassed Reunion melt inclusions, ranging from $\Delta \mathrm{QFM}=-0.5$ to +0.1 , with an ocean basin average value of $\Delta \mathrm{QFM}=-0.1 \pm 0.1$ (Fig. 7).

The estimate of the $f \mathrm{O}_{2}$ of the mantle source of the 2005 Piton de la Fournaise primary liquid presented here (and by other studies of Reunion Island lavas; see Fig. 1b and Pichavant 2016; Gaborieau et al. 2020; Peters et al. 2019) is significantly lower (i.e., outside of analytical uncertainty of $\pm 0.01 \mathrm{Fe}^{3+} / \Sigma \mathrm{Fe} ; \pm 0.25 \log$ units $f \mathrm{O}_{2}$ ) than recently published estimates of the $f \mathrm{O}_{2}$ of the mantle sources of other ocean island lavas based on similar analytical approaches and primary melt reconstructions (Figs. 1a, 7). Moreover, the $f \mathrm{O}_{2} \mathrm{~s}$ inferred for mantle sources of lavas from Hawaii $(\triangle \mathrm{QFM}=+0.5$ to +0.6 ; Brounce et al. 2017; Helz et al. 2017; Moussallam et al. 2016), Iceland $(\Delta \mathrm{QFM}=+0.4$ to + 0.5; Hartley et al. 2017; Shorttle et al. 2015; Novella et al. 2020), Mount Erebus ( $\triangle \mathrm{QFM}=+1.7$; Moussallam et al. 2014) and the Canaries ( $\Delta \mathrm{QFM}>+2$; Moussallam et al. 2019) are all significantly higher than the $f_{2}$ estimates of the upper mantle that feeds the mid-ocean ridge system in their respective ocean basins (Moussallam et al. 2019). In contrast, the estimate of the $f \mathrm{O}_{2}$ relative to QFM of the Reunion source presented here ( $\Delta \mathrm{QFM} \sim-0.2$ to 0$)$ cannot be distinguished from that of the Indian upper mantle $(\Delta \mathrm{QFM}=-0.5$ to +0.1 ; Birner et al. 2018; Zhang et al. 2018). This is a key result of our study, demonstrating that not all OIB magmas record higher $f_{2} \mathrm{~s}$ in their sources than ambient upper mantle as represented by the sources of MORBs from the same ocean basin, contrary to the conclusion of Moussallam et al. (2019).

The Reunion samples we have studied have $\mathrm{Pb}$ isotope ratios resembling the so-called DUPAL anomaly and elevated ${ }^{87} \mathrm{Sr} /{ }^{86} \mathrm{Sr}$ relative to DMM (Bosch et al. 2008). If these isotopic characteristics are due to the presence of oxidized recycled materials in the sources of Reunion magmas, they must be present in proportions too small to elevate significantly the $f \mathrm{O}_{2}$ of Reunion magmas above that of the DMM reservoir sampled by Indian Ocean MORB. Furthermore, as much as $60-90 \%$ of the Reunion mantle source has been suggested to consist of the C/FOZO/PREMA component (Bosch et al. 2008). To the extent that this isotopically defined mantle component of many OIB lavas reflects a specific mantle lithology with a well-defined origin and history, our results suggest that this component has an $f \mathrm{O}_{2}$ of $\Delta \mathrm{QFM} \approx 0$ at $~ 3$ $\mathrm{GPa}$ and $1350{ }^{\circ} \mathrm{C}$, not significantly different from that of $\mathrm{DMM}$ at $\sim 1 \mathrm{GPa}$ and $1250{ }^{\circ} \mathrm{C}$ (i.e., the dominant upper mantle reservoir). If this is correct, it would argue against significant contributions of oceanic crust recycled in the last
400-800 my to the C/FOZO/PREMA mantle component, because more recently generated oceanic crust is inferred to have become significantly oxidized during their time at or near Earth's surface (e.g., Lecuyer and Ricard, 1999; Stolper and Keller 2018).

There are many factors that could influence the $f \mathrm{O}_{2}$ of a partial melt of the mantle including: the major element composition of the source, which influences the mineralogy and phase equilbria under both subsolidus and supersolidus conditions as functions of $\mathrm{P}$ and $\mathrm{T}$ and could lead to variations of at least one order of magnitude in $\mathrm{fO}_{2}$ (e.g., Jennings and Holland, 2015; Stolper et al. 2020); the concentrations and oxidation states of heterovalent elements in the source, including not only Fe, but also H, C, S, and more (e.g., Frost and McCammon 2008 and references therein); and the flow of fluids through the source (e.g., Frost and McCammon 2008 and references therein). Given these and other possible factors that could influence the $f_{2}$ levels of the mantle sources of magmas, it is difficult at this time to decode the significance of the essentially identical $f_{2}$ levels of magmas from the C/FOZO/PREMA-rich Reunion plume source (as defined by this study and previous studies of different lavas from Reunion island, Fig. 1b) and MORB magmas from the global upper mantle DMM source. Given the sensitivity of $f \mathrm{O}_{2}$ to so many factors, this close correspondence is unlikely to be a coincidence, although this cannot be ruled out. One possible explanation for this similarity is that melt extraction \pm addition processes similar to those acting on mantle corresponding to the bulk silicate earth that resulted in the chemical composition of the DMM source-including its $f \mathrm{O}_{2}$-also had a significant role in the generation of the apparently widespread C/FOZO/PREMA source early in Earth history. In this scenario, a simple explanation for the differences between the Reunion source and the sources of OIBs with mantle sources that record higher $f_{2}$ s reflects the larger contributions to the sources of these other OIBS of higher $f \mathrm{O}_{2}$, recycled EMI, EMII and HIMU source components. If this is correct, it suggests that the various shared characteristics of Reunion and other, more oxidized OIB magmas (i.e., at Hawaii, Iceland, Canary Islands, Erebus)such as elevated pressures and temperatures of melting and larger amounts of crystal fractionation at higher average pressures than typical MORBs- do not uniquely set the $f \mathrm{O}_{2}$ of OIB magmas since otherwise, Reunion magmas would be expected to be as oxidized as Hawaiian, Icelandic, Canary Island, and Erebus magmas.

Finally, we point out that there is substantial isotopic heterogeneity of the C/FOZO/PREMA component (as there is in DMM, EM1, EM2, HIMU components as well, e.g., Stracke et al. 2005) globally and it is possible that this extends to $f \mathrm{O}_{2}$ as well. At this time there are not to our knowledge other constraints on the $f \mathrm{O}_{2}$ of $\mathrm{C} / \mathrm{FOZO} / \mathrm{PREMA}$ component. Additional studies of relatively undegassed magma compositions 
(including $f \mathrm{O}_{2}$ ) at locations that sample $\mathrm{C} / \mathrm{FOZO} / \mathrm{PREMA}$ without significant additions of EM1, EM2, and HIMU components (which may be very oxidized, see Sect. 4.4.) will be necessary to assess this.

\section{Heterogeniety in mantle source $\mathrm{fO}_{2}$ and radiogenic isotope ratios}

We have emphasized that the elevated $\mathrm{Fe}^{3+} / \Sigma \mathrm{Fe}$ ratios and inferred $f \mathrm{O}_{2}$ levels of relatively undegassed glasses from Hawaii, Iceland, the Canaries, and Mount Erebus relative to MORB and Reunion magmas have been suggested as being related to the presence in their mantle sources of isotopically enriched EM1 and HIMU components that are oxidized relative to DMM (Brounce et al. 2017; Hartley et al. 2017; Moussallam et al. 2014, 2016, 2019; Shorttle et al. 2015; Novella et al. 2020). Although, as discussed above, many factors can influence the $f \mathrm{O}_{2}$ levels of the mantle sources of basaltic magmas, in this final section, we extend the modeling by Jackson et al. (2020) of source mixing (constrained by variations in radiogenic isotope ratios in OIBs) to include their $\mathrm{Fe}^{3+} / \Sigma \mathrm{Fe}$ ratios. The goal of this modeling is to evaluate semi-quantitatively whether the differences in $f \mathrm{O}_{2}$ estimates for the Hawaiian and Icelandic sources on one hand $(\Delta \mathrm{QFM} \sim+0.4$ to +0.6 ; Brounce et al. 2017; Hartley et al. 2017; Moussallam et al. 2016; Shorttle et al. 2015; Novella et al. 2020) and for Mount Erebus and the Canary Islands on the other $(\Delta \mathrm{QFM} \gtrsim+2$; Moussallam 2014,2019$)$ are consistent with the proportions of mantle end members in their sources based on radiogenic isotopic ratios. For example, one simple model would be that EM1, EM2, and HIMU end members have similar major element compositions (including $\mathrm{Fe}^{3+} / \Sigma \mathrm{Fe}$ ratios), in which case they would typically have similar $f \mathrm{O}_{2}$ at a given $\mathrm{P}$ and $\mathrm{T}$. If these end members were mixed with other source components (e.g., DMM, EM1, EM2, HIMU), again with major element compositions of the enriched components assumed to be similar, then if Hawaiian and Icelandic mantle sources contained lower proportions of recycled surface materials relative to the sources of Mount Erebus/Canary Islands, this could explain the lower $\mathrm{Fe}^{3+} / \Sigma \mathrm{Fe}$ ratios (and lower inferred $f \mathrm{O}_{2} \mathrm{~s} ;$ Fig. 7) of Hawaiian/Icelandic basaltic glasses.

We have evaluated this type of mixing model semi-quantitatively using the model of Jackson et al. (2020) to constrain the proportions of the isotopically defined (and distinguishable) end members in the sources of the OIBs; then, assuming values for the $\mathrm{Fe}^{3+} / \Sigma \mathrm{Fe}$ ratios of the isotopically defined end members, we evaluate whether the isotopic and $\mathrm{Fe}^{3+}$ / $\Sigma \mathrm{Fe}$ ratios can be simulatenously satisified for the Hawaiian, Icelandic, Canary Islands, and Erebus OIBs given the proportions of the end members in their sources based on the isotopc ratios of the OIBs from Jackson et al. (2020). To simplify this exercise, we assume that all melts of all end members have $11 \mathrm{wt} \% \mathrm{FeO}^{*}$ and that melts of EM1, EM2, and HIMU all have the same $\mathrm{Fe}^{3+} / \Sigma \mathrm{Fe}$ ratio, corresponding to that of altered oceanic crust, as represented by the "Super Composite" of seafloor sediments and altered oceanic crust recovered from the Pacific ocean crust at ODP Site $801\left(\mathrm{Fe}^{3+} /\right.$ $\Sigma \mathrm{Fe} \sim 0.5$, see Brounce et al. 2019). We also assume that a partial melt of DMM has $\mathrm{Fe}^{3+} / \Sigma \mathrm{Fe}=0.12$ (Cottrell and Kelley 2011; Zhang et al. 2018). We then mix the partial melt of DMM and melts of the enriched source components in various proportions between 0 and 1 (i.e., duplicating the approach of Jackson et al. 2020) to generate the solid blue, orange, and gray mixing curves shown in Fig. 7 for mixtures of DMM with EM1, HIMU, and EM2, respectively; the DSr$\mathrm{Nd}-\mathrm{Pb}$ parameter shown on the $\mathrm{x}$-axis is defined by Jackson et al. (2020) and is calculated for each mixing ratio (and for each of the basalt samples shown as colored dots in Fig. 7) using the endmember $\mathrm{Sr}$ and $\mathrm{Pb}$ concentrations and ${ }^{87} \mathrm{Sr} /{ }^{86} \mathrm{Sr}$ and ${ }^{206} \mathrm{~Pb} /{ }^{204} \mathrm{~Pb}$ ratios of melts of EM1, HIMU, and DMM estimated by Jackson et al. (2020).

For both Iceland and Hawaii, the estimated proportions of EM1 in their sources based on their radiogenic isotope ratios (DSr-Nd-Pb $=0.35 \pm 0.07$, DSr-Nd-Pb $=0.33 \pm 0.04$, respectively) are about $5 \%$ based on their radiogenic isotope ratios based on Jackson et al. (2020); this estimate is consistent with other estimates of the proportion of enriched components for Hawaiian magmas on the basis of other isotope systems and trace elements of 4-20\% (Eiler et al. 1996; Hauri et al. 1996; Sobolev et al. 2007). The proportions of the EM1 endmember in the source required to match the $\mathrm{Fe}^{3+} / \Sigma \mathrm{Fe}$ ratios of relatively undegassed Hawaiian and Icelandic glasses given the parameters described above are $~ 15 \%$ EM1 (based on the tick marks on the blue curve in Fig. 7). This overlaps the upper end of the range of estimated EM1 proportions based on radiogenic isotopes and demonstrates that the amount of EM1 in Hawaiian and Icelandic sources based on $\mathrm{Fe}^{3+} / \Sigma \mathrm{Fe}$ and isotopic ratios are compatible.

For the Canary Islands, the estimated proportions of HIMU in their sources are about $30 \%$ from their radiogenic isotope ratios ( $\mathrm{DSr}-\mathrm{Nd}-\mathrm{Pb}=0.55 \pm 0.06$ ) based on Jackson et al. (2020); as for Hawaii and Iceland, this is again broadly consistent with previous esimates of 10-35\% HIMU component in the sources of Canary Island magmas (Widom et al. 1999; Day et al. 2010). The proportions of the HIMU end member in the source required to match the $\mathrm{Fe}^{3+} / \Sigma \mathrm{Fe}$ ratios of relatively undegassed Canary Island glasses are 40\% (based on the tick marks on the solid orange curve in Fig. 7), again consistent with the range of estimated HIMU proportions based on radiogenic isotopes. Finally, for Mount Erebus, the estimated proportions of HIMU in the sources from radiogenic isotopes is $\sim 40 \%$ (DSr- $\mathrm{Nd}-\mathrm{Pb}=0.63 \pm 0.03$ ) based on Jackson et al. (2020) and 35-95\% based on Phillips et al. (2018). The proportions of the HIMU end member in the source required to match the $\mathrm{Fe}^{3+} / \Sigma \mathrm{Fe}$ ratios of relatively 
undegassed Erebus glasses are 55\% (based on the tick marks on the solid orange curve in Fig. 7), consistent with the range of estimated HIMU proportions based on radiogenic isotopes. Given the unrealistically simple assumptions of this mixing model, we are encouraged by the overall level of agreement between the higher amounts of HIMU in their sources implied by the isotopes of the Canary Islands and Erebus samples relative to amounts of the EM1 components implied for the sources of the Hawaii and Iceland samples and the success of the mixing model in explaining simultaneously the isotopic ratios and $\mathrm{Fe}^{3+} / \Sigma \mathrm{Fe}$ ratios presented here for these four OIB. We also considered the possibility that the EM1, EM2, and HIMU end members have a higher $\mathrm{Fe}^{3+}$ / $\Sigma \mathrm{Fe}$ ratio. If we assume that partial melts of the end-member source components have $\mathrm{Fe}^{3+} / \Sigma \mathrm{Fe} \sim 0.7$, the fit of these simple mixing models (shown by the dashed curves in Fig. 7) to the radiogenic isotopic compositions and estimates of the $\mathrm{Fe}^{3+} / \Sigma \mathrm{Fe}$ of the least degassed magmas at each location is improved, but there are so many uncertainties in the model in detail that we do not regard this improvement as significant. For example, including the likely higher melt productivity of the enriched components relative to DMM would produce the same sense of change introduced by assuming a higher $\mathrm{Fe}^{3+} /$ $\Sigma \mathrm{Fe}$ ratio in the enriched sources, and the assumptions about the total Fe contents of the partial melts and/or the source components would also have consequences.

Overall, however, although the mixing model coupling radiogenic isotopic ratios and $\mathrm{Fe}^{3+} / \Sigma \mathrm{Fe}$ ratios depends on many simplifying assumptions and approximations that can be challenged, they demonstrate that the $\mathrm{Fe}^{3+} / \Sigma \mathrm{Fe}$ ratios in OIB glasses from Hawaii, Iceland, the Canary Islands, and Mt. Erebus can be explained semi-quantitatively by a simple mixing model using proportions of DMM and EM1 or HIMU components in their sources based on the radiogenic isotope ratios of basaltic rocks from these OIBs. It remains to be seen if glasses from other OIBs can be similarly explained, but this can be readily tested with measurements of the $\mathrm{Fe}^{3+} / \Sigma \mathrm{Fe}$ of magmas whose isotopic compositions reflect significant and variable contributions from these same endmembers-such as St. Helena, Tubaii, Rurutu, Mangaia, and Rimatara islands for HIMU (Stracke et al. 2003) and Tristan da Cunha, Pitcairn, and Kerguelen islands for EM1 (Stracke et al. 2003). Additionally, the model predicts the behavior of the EM2 component, represented by Society, Samoa, and Marquesas islands, for example (Stracke et al. 2003), for which $\mathrm{Fe}^{3+} / \Sigma \mathrm{Fe}$ ratios are currently unavailable.

\section{Conclusions}

Olivine-hosted melt inclusions from the 2005 Piton de la Fournaise eruption at Reunion Island have $\mathrm{Fe}^{3+} / \Sigma \mathrm{Fe}$ ratios that are indistinguishable from those of Indian Ocean
MORB, in contrast to the recent suggestion that all ocean island basaltic magmas are more oxidized than MORB (e.g., Moussallam et al. 2019). The $\mathrm{Fe}^{3+} / \Sigma \mathrm{Fe}$ ratios of these inclusions correlate weakly with measured $\mathrm{H}_{2} \mathrm{O}$ concentrations but not with $\mathrm{S}$; this can be explained by incomplete diffusive reequilibration of $\mathrm{Fe}^{3+} / \Sigma \mathrm{Fe}$ and $\mathrm{H}_{2} \mathrm{O}$ of the melt inclusions through the olivine hosts with a degassed and thus reduced external magma. The least degassed inclusions are used to reconstruct the $f \mathrm{O}_{2}$ of the primary magmas from which they were derived, at the mantle conditions under which they likely equilibrated with their mantle sources; this reconstruction suggests that the mantle sources of the 2005 Piton de la Fournaise eruption had $f \mathrm{O}_{2}$ levels corresponding to $\triangle \mathrm{QFM}$ $0.1 \pm 0.1$ (also indistinguishable from reconstructed MORB primary melts). Because the mantle source of magmas at Piton de la Fournaise are thought to consist of $\sim 60-90 \%$ of the C/FOZO/PREMA mantle component, this suggests the $f \mathrm{O}_{2}$ of this mantle component is essentially indistinguishable from that of DMM. This in turn may suggest that the igneous processes that led to the well-defined and similar $f_{2}$ of both the DMM and C/FOZO/PREMA reservoirs (e.g., melt extraction and/or addition relative to initially similar reservoirs) either did not result in major changes in $f \mathrm{O}_{2}$ relative to bulk silicate Earth and/or led to similar changes for both DMM and C/FOZO/PREMA. Although the C/FOZO/PREMA component present in the sources of Reunion magmas is not oxidized relative to DMM, the sources of other OIBs with significant contributions of EM1 and HIMU mantle components based on available radiogenic isotopic ratios are more oxidized than DMM based on available data. Simple semiquantitative mixing models couple plausibly elevated $\mathrm{Fe}^{3+}$ / $\Sigma$ Fe ratios of EM1, EM2, and HIMU components and their radiogenic isotopic compositions to variations in their contributions to the primary melts of OIB. The exact $f \mathrm{O}_{2}$ levels (and $\mathrm{Fe}^{3+} / \Sigma \mathrm{Fe}$ ratios) of these reservoirs, (and that of EM2), and whether HIMU and EM1 are similarly oxidized (as suggested by Moussallam et al. 2019) or not, requires additional analyses of glasses from oceanic volcanos in which the EM1, EM2, and HIMU endmembers are thought to represent high fractions of their mantle sources.

Supplementary Information The online version contains supplementary material available at https://doi.org/10.1007/s00410-021-01870-w.

Acknowledgements We are grateful to have received constructive reviews from Fabrice Gaillard and Brad Peters that improved this manuscript. We are also grateful for the careful handling of editor Dante Canil. We thank Pascal Richet for generously providing sample for this study. We thank C. Ma for assistance in microprobe analyses, and L. Saper for discussion of $\mathrm{Fe}$ and $\mathrm{S}$ redox, at the California Institute of Technology. We also thank A. Lanzirotti and M. Newville for assistance in beamline operations at Advanced Photon Source Argonne National Laboratory (APS ANL). Portions of this work were performed at GeoSoilEnviroCARS (The University of Chciago, Sector 13), Advanced Photon Source (APS), Argonne National Laboratory. GeoSoilEnviroCARS is supported by the National Science 
Foundation - Earth Sciences (EAR-1634415) and Department of Energy GeoSciences (DE-FG02-94ER14466). This research used resources of the Advanced Photon Source, a U.S. Department of Energy (DOE) Office of Science User Facility operated for the DOE Office of Science by Argonne National Laboratory under Contract No. DE-AC02-06CH11357.

Open Access This article is licensed under a Creative Commons Attribution 4.0 International License, which permits use, sharing, adaptation, distribution and reproduction in any medium or format, as long as you give appropriate credit to the original author(s) and the source, provide a link to the Creative Commons licence, and indicate if changes were made. The images or other third party material in this article are included in the article's Creative Commons licence, unless indicated otherwise in a credit line to the material. If material is not included in the article's Creative Commons licence and your intended use is not permitted by statutory regulation or exceeds the permitted use, you will need to obtain permission directly from the copyright holder. To view a copy of this licence, visit http://creativecommons.org/licenses/by/4.0/.

\section{References}

Albarède F, Tamagnan V (1988) Modelling the recent geochemical evolution of the piton de la Fournaise volcano, Reunion Island, 1931-1986*. J Petrol 29:997-1030. https://doi.org/10.1093/petro $\log / 29.5 .997$

Albarède F, Luais B, Fitton G, Semet M, Kaminski E, Upton BGJ, Bachèlery P, Cheminée J-L (1997) The geochemical regimes of piton de la Fournaise volcano (Réunion) during the last 530000 years. J Petrol 38:171-201. https://doi.org/10.1093/petroj/38.2.171

Anderson AT, Wright TL (1972) Phenocrysts and glass inclusions and their bearing on oxidation and mixing of basaltic magmas, Kilauea Volcano, Hawaii. Am Min 57:188-216

Berry AJ, Stewart GA, O'Neill H, St C, Mallmann G, Mosselmans JFW (2018) A re-assessment of the oxidation state of iron in MORB glasses. Earth Planet Sci Lett 483:114-123. https://doi.org/10. 1016/j.epsl.2017.11.032

Birner SK, Cottrell E, Warren JM, Kelley KA, Davis FA (2018) Peridotites and basalts reveal broad congruence between two independent records of mantle $f \mathrm{O}_{2}$ despite local redox heterogeneity. Earth Planet Sci Lett 494:172-189. https://doi.org/10.1016/j.eps1.2018. 04.035

Bosch D, Blichert-Toft J, Moynier F, Nelson BK, Telouk P, Gillot P-Y, Albarède $\mathrm{F}$ (2008) $\mathrm{Pb}$, Hf and $\mathrm{Nd}$ isotope compositions of the two Réunion volcanoes (Indian Ocean): A tale of two small-scale mantle "blobs"? Earth Planet. Sci Lett 265:748-765. https://doi.org/10. 1016/j.eps1.2007.11.018

Boyet M, Doucelance R, Israel C, Bonnand P, Auclair D, Suchorksi K, Bosq C (2019) New constraints on the origin of EM-1 Component revealed by the measurement of the $\mathrm{La}-\mathrm{Ce}$ isotope systematics in Gough Island lavas. Geochem Geosyst Geophys. https://doi.org/ 10.1029/2019GC008228

Borisov A, Behrens H, Holtz F (2018) Ferric/ferrous ratio in silicate melts: a new model for $1 \mathrm{~atm}$ data with special emphasis on the effects of melt composition. Contri Mineral Petrol 173(12):98. https://doi.org/10.1007/s00410-018-1524-8

Boudoire G, Rizzo AL, Di Muro A, Grass F, Liuzzo M (2018) Extensive $\mathrm{CO}_{2}$ degassing in the upper mantle beneath oceanic basaltic volcanoes: First insights from Piton de la Fournaise volcano (La Reunion Island). Geochimica et Cosmochimica Acta 235:376401. https://doi.org/10.1016/j.gca.2018.06.004 .
Brounce MN, Kelley KA, Cottrell E (2014) Variations in $\mathrm{Fe}^{3+} / \sum \mathrm{Fe}$ of mariana Arc Basalts and Mantle Wedge $f \mathrm{O}_{2}$. J Petrol 55:25132536. https://doi.org/10.1093/petrology/egu065

Brounce M, Stolper E, Eiler J (2017) Redox variations in Mauna Kea lavas, the oxygen fugacity of the Hawaiian plume, and the role of volcanic gases in Earth's oxygenation. Proc Natl Acad Sci 114:8997. https://doi.org/10.1073/pnas.1619527114

Brounce M, Cottrell E, Kelley KA (2019) The redox budget of the Mariana subduction zone. Earth Planet Sci Lett 528:115859. https://doi. org/10.1016/j.epsl.2019.115859

Bucholz CE, Gaetani GA, Behn MD, Shimizu N (2013) Post-entrapment modification of volatiles and oxygen fugacity in olivine-hosted melt inclusions. Earth Planet Sci Lett 374:145-155. https://doi. org/10.1016/j.epsl.2013.05.033

Bureau H, Pineau F, Metrich N, Javoy M (1998a) A melt and fluid inclusion study of the gas phase at Piton de la Fournaise volcano (Réunion Island). Chem Geol 147:115-130

Bureau H, Metrich N, Semet MP (1998b) Magma-conduit interaction at Piton de la Fournaise (Réunion Island): a melt and fluid inclusion study. J Volc Geotherm Res 84:39-60

Burgisser A, Scaillet B (2007) Redox evolution of a degassing magma rising to the surface. Nature 445:194-197

Burgisser A, Alletti M, Scaillet B (2015) Simulating the behavior of volatiles belonging to the $\mathrm{C}-\mathrm{O}-\mathrm{H}-\mathrm{S}$ system in silicate melts under magmatic conditions with the software D-Compress. Comput Geosci 79:1-14. https://doi.org/10.1016/j.cageo.2015.03.002

Candela PA (1986) The evolution of aqueous vapor from silicate melts: Effect on oxygen fugacity. Geochim Cosmochim Acta 50:1205-1211

Carmichael ISE, Ghiorso MS (1986) Oxidation-reduction relations in basic magma: a case for homogeneous equilibria. Earth Planet Sci Lett 78:200-210. https://doi.org/10.1016/0012-821X(86)90061-0

Castillo $\mathrm{P}$ (2015) The recycling of marine carbonates and sources of HIMU and FOZO ocean island basalts. Lithos 216-217:254-263. https://doi. org/10.1016/j.lithos.2014.12.005

Chauvel C, Hofmann AW, Vidal P (1992) himu-em: The French Polynesian connection. Earth Planet Sci Lett 110:99-119. https://doi.org/ 10.1016/0012-821X(92)90042-T

Cordier C, Delavault H, Chauvel C (2021) Geochemistry of the Society and Pitcairn-Gambier mantle plumes: What they share and do not share. Geochim Cosmochim Acta 306:362-384. https://doi.org/10. 1016/j.gca.2021.04.014

Cottrell E, Kelley KA (2011) The oxidation state of Fe in MORB glasses and the oxygen fugacity of the upper mantle. Earth Planet Sci Lett 305:270-282. https://doi.org/10.1016/j.eps1.2011.03.014

Cottrell E, Kelley KA, Lanzirotti A, Fischer RA (2009) High-precision determination of iron oxidation state in silicate glasses using XANES. Chem Geol 268:167-179. https://doi.org/10.1016/j.chemgeo.2009. 08.008

Danyuskevsky LV, Plechov P (2011) Petrolog3: integrated software for modeling crystallization processes. Geochem Geophys Geosyst 12:Q07021. https://doi.org/10.1029/2011GC03516

Davis FA, Cottrell E (2018) Experimental investigation of basalt and peridotite oxybarometers: Implications for spinel thermodynamic models and $\mathrm{Fe} 3+$ compatibility during generation of upper mantle melts. Am Mineral 103:1056-1067. https://doi.org/10.2138/am-2018-6280

Day JMD, Pearson DG, Macpherson CG, Lowry D, Carracedo JC (2010) Evidence for distinct proportions of subducted oceanic crust and lithosphere in HIMU-type mantle beneath El Hierro and La Palma, Canary Islands. Geochim Et Cosmochim Acta 74:6565-6589. https:// doi.org/10.1016/j.gca.2010.08.021

Dupré B, Allègre CJ (1983) Pb-Sr isotope variation in Indian Ocean basalts and mixing phenomena. Nature 303:142-146. https://doi. org/10.1038/303142a0

Eiler JM, Farley KA, Valley JW, Hoffman AW, Stolper EM (1996) Oxygen isotope constraints on the sources of Hawaiian volcanism. Earth 
and Planet. Sci. Lett. 144:453-469. https://doi.org/10.1016/S0012821X(96)00170-7

Famin V, Welsch B, Okumura S, Bachèlery P, Nakashima S (2009) Three differentiation stages of a single magma at Piton de la Fournaise volcano (Reunion hot spot). Geochem Geophys Geosystems. https://doi.org/10.1029/2008GC002015

Frost DJ, McCammon CA (2008) The Redox State of Earth's Mantle. Annu Rev Earth Planet Sci 36:389-420. https://doi.org/10.1146/ annurev.earth.36.031207.124322

Gaborieau M, Laubier M, Bolfan-Casanova N, McCammon CA, Vantelon D, Chumakov AI, Schiavi F, Neuville DR, Venugopal S (2020) Determination of $\mathrm{Fe}^{3+} / \sum \mathrm{Fe}$ of olivine-hosted melt inclusions using Mossbauer and XANES spectroscopy. Chem Geol 547:119646. https://doi.org/10.1016/j.chemgeo.2020.119646

Gaetani GA, O’Leary JA, Shimizu N, Bucholz CE, Newville M (2012) Rapid reequilibration of $\mathrm{H} 2 \mathrm{O}$ and oxygen fugacity in olivinehosted melt inclusions. Geology 40:915-918. https://doi.org/10. 1130/G32992.1

Gaillard F, Scaillet B, Arndt N (2011) Atmospheric oxygenation caused by a change in volcanic degassing pressure. Nature 478:229-232. https://doi.org/10.1038/nature10460

Gaillard F, Scaillet B, Pichavant M, Iacono-Marziano G (2015) The redox geodynamics linking basalts and their mantle sources through space and time. Chem. Geol. 418:217-233. https://doi. org/10.1016/j.chemgeo.2015.07.030

Garapic G, Jackson MG, Hauri EH, Hart SR, Farley KA, Blusztajn JS, Woodhead JD (2015) A radiogenic isotope (He-Sr-Nd-Pb-Os) study of lavas from Pitcarin hotspot: Implications for the origin of EM-1 (enriched mantle 1). Lithos 228-229:1-11. https://doi.org/ 10.1016/j.lithos.2015.04.010

Giuliani A, Jackson MG, Fitzpayne A, Dalton H (2021) Remnants of early Earth differentiation in the deepest mantle-derived lavas. PNAS. https://doi.org/10.1073/pnas.2015211118

Hanan BB, Graham DW (1996) Lead and helium isotope evidence from oceanic basalts for a common deep source of mantle plumes. Science 272:991. https://doi.org/10.1126/science.272.5264.991

Hart SR (1984) A large-scale isotope anomaly in the Southern Hemisphere mantle. Nature 309:753-757. https://doi.org/10.1038/30975 $3 \mathrm{a} 0$

Hart SR, Hauri EH, Oschmann LA, Whitehead JA (1992) Mantle plumes and entrainment: isotopic evidence. Science 256:517. https://doi.org/10.1126/science.256.5056.517

Hartley ME, Shorttle O, Maclennan J, Moussallam Y, Edmonds M (2017) Olivine-hosted melt inclusions as an archive of redox heterogeneity in magmatic systems. Earth Planet Sci Lett 479:192-205. https://doi.org/10.1016/j.epsl.2017.09.029

Hauri EH, Whitehead JA, Hart SR (1994) Fluid dynamic and geochemical aspects of entrainment in mantle plumes. J Geophys Res 99:24275-24300

Hauri EH, Lassiter JC, DePaolo DJ (1996) Osmium isotope systematics of drilled lavas from Mauna Loa, Hawaii. J Geophys Res Solid Earth 101:11793-11806

Helz RT, Cottrell E, Brounce MN, Kelley KA (2017) Olivine-melt relationships and syneruptive redox variations in the 1959 eruption of Kīlauea Volcano as revealed by XANES. J Volcanol Geotherm Res 333-334:1-14. https://doi.org/10.1016/j.jvolgeores.2016.12.006

Helz RT, Thornber CR (1987) Geothermometry of Kilauea Iki lava lake, Hawaii. Bull Volc 49:651-668. https://doi.org/10.1007/ BF01080357

Herzberg C, Asimow PD (2008) Petrology of some oceanic island basalts: PRIMELT2.XLS software for primary magma calculation. Geochem Geophys Geosystems. https://doi.org/10.1029/ 2008GC002057

Hofmann AW, White WM (1982) Mantle plumes from ancient oceanic crust. Earth Planet Sci Lett 57:421-436. https://doi.org/10.1016/ 0012-821X(82)90161-3
Jackson MG, Blichert-Toft J, Halldórsson SA, Mundl-Petermeier A, Bizimis M, Kurz MD, Price AA, Hardardóttir S, Willhite LN, Breddam K, Becker TW, Fischer R (2020) Ancient helium and tungsten isotopic signatures preserved in mantle domains least modified by crustal recycling. PNAS 117:30993-31001

Jayasuriya KD, O’Neill H St. C, Berry, AJ, Campbell SJ (2004) A Mössbauer study of the oxidation state of Fe in silicate melts. Am Mineral 89(11-12):1597-1609. https://doi.org/10.2138/ am-2004-11-1203

Jenner FE, O'Neill H, St C (2012) Analysis of 60 elements in 616 ocean floor basaltic glasses. Geochem Geophys Geosystems. https://doi. org/10.1029/2011GC004009

Jennings ES, Holland TJB (2015) A simple thermodynamic model for melting of peridotite in the system NCFMASOCr. J Petrol 56:869-892

Kelley KA, Cottrell E (2009) Water and the oxidation state of subduction zone magmas. Science 325:605-607

Kelley KA, Cottrell E (2012) The influence of magmatic differentiation on the oxidation state of $\mathrm{Fe}$ in a basaltic arc magma. Earth Planet Sci Lett 329-330:109-121. https://doi.org/10.1016/j.epsl. 2012.02.010

Langmuir CH, Klein EM, Plank T (1992) Petrological systematics of mid-ocean ridge basalts: constraints on melt generation beneath ocean ridges. Geophys Monogr Ser 71:183-280

Le Voyer M, Asimow PD, Mosenfelder JL, Guan Y, Wallace PJ, Schiano P, Stolper EM, Eiler JM (2014) Zonation of H2O and $\mathrm{F}$ concentrations around melt inclusions in olivines. J Petrol 55:685-707. https://doi.org/10.1093/petrology/egu003

Lecuyer C, Ricard Y (1999) Long-term fluxes and budget of ferric iron: implication for the redox states of the Earth's mantle and lithosphere. Earth Plant Sci Lett 165:197-211. https://doi.org/ 10.1016/S0012-821X(98)00267-2

Metrich N, Berry AJ, O’Neill H, St C, Susini J (2009) The oxidation state of sulfur in synthetic and natural glasses determined by X-ray absorption spectroscopy. Geochim Cosmochim Acta 73:2382-2399. https://doi.org/10.1016/j.gca.2009.01.025

Moussallam Y, Oppenheimer C, Scaillet B, Gaillard F, Kyle P, Peters N, Hartley M, Berlo K, Donovan A (2014) Tracking the changing oxidation state of Erebus magmas, from mantle to surface, driven by magma ascent and degassing. Earth Planet Sci Lett 393:200-209. https://doi.org/10.1016/j.eps1.2014.02.055

Moussallam Y, Edmonds M, Scaillet B, Peters N, Gennaro E, Sides I, Oppenheimer C (2016) The impact of degassing on the oxidation state of basaltic magmas: A case study of Kilauea volcano. Earth Planet Sci Lett 450:317-325. https://doi.org/10.1016/j. eps1.2016.06.031

Moussallam Y, Longpré M-A, McCammon C, Gomez-Ulla A, RoseKoga EF, Scaillet B, Peters N, Gennaro E, Paris R, Oppenheimer C (2019) Mantle plumes are oxidised. Earth Planet Sci Lett 527:115798. https://doi.org/10.1016/j.eps1.2019.115798

Nash WM, Smythe DJ, Wood BJ (2019) Compositional and temperature effects on sulfur speciation and solubility in silicate melts. Earth Planet Sci Lett 507:187-198. https://doi.org/10.1016/j. epsl.2018.12.006

Newcombe ME, Fabbrizio A, Zhang Y, Ma C, Le Voyer M, Guan Y, Eiler JM, Saal AE, Stolper EM (2014) Chemical zonation in olivine-hosted melt inclusions. Contrib Mineral Petrol 168:1030. https://doi.org/10.1007/s00410-014-1030-6

Newcombe ME, Plank T, Barth A, Asimow PD, Hauri EH (2020) Water-in-olivine magma ascent chronometry: Every crystal is a clock. J Volc Geophys Res 398:106872. https://doi.org/10. 1016/j.volgeores.2020.106872

Novella D, Maclennan J, Shorttle O, Prytulak J, Murton BJ (2020) A multi-proxy investigation of mantle oxygen fugacity along the Reykjanes Ridge. Earth Planet. Sci. Lett. 531:115973 
O'Neill H, St C, Berry AJ, Mallmann G (2018) The oxidation state of iron in Mid-Ocean Ridge Basaltic (MORB) glasses: Implications for their petrogenesis and oxygen fugacities. Earth Planet Sci Lett 504:152-162. https://doi.org/10.1016/j.epsl.2018.10.002

O'Neill H, St C, Mavrogenes J (2002) The sulfide capacity and the sulfur content at sulfide saturation of silicate melts at $1400 \mathrm{C}$ and 1 bar. J Petrol 43:1049-1087. https://doi.org/10.1093/petrology/ 43.6.1049

Peters BJ, Shahar A, Carlson RW, Day JMD, Mock TD (2019) A sulfide perspective on iron isotope fractionation during ocean island basalt petrogenesis. Geochim Cosmochim Acta 245:59-78. https://doi. org/10.1016/j.gca.2018.10.015

Philipps EH, Sims KWW, Blichert-Toft J, Aster RC, Gaetani GA, Kyle PR, Wallace PJ, Rasmussen DJ (2018) The nature and evolution of mantle upwelling at Ross Island, Antarctica, with implications for the source of HIMU lavas. Earth Planet Sci Lett 498:38-53. https://doi.org/10.1016/j.epsl.2018.05.049

Pichavant M, Brugier Y, Di Muro A (2016) Petrological and experimental constraints on the evolution of Piton de la Fournaise magmas. Active Volcanoes of the Southwest Indian Ocean. Springer Publishing, 171-184

Roeder PL, Emslie RF (1970) Olivine-liquid equilibrium. Contrib Mineral Petrol 29:275-289. https://doi.org/10.1007/BF00371276

Rowe MC, Kent AJR, Nielsen RL (2007) Determination of sulfur speciation and oxidation state of olivine hosted melt inclusions. Chem Geol 236:303-322. https://doi.org/10.1016/j.chemgeo.2006.10.007

Saper LM, Stolper EM (2020) Controlled cooling-rate experiments on olivine-hosted melt inclusions: chemical diffusion and quantification of eruptive cooling rates on Hawaii and Mars. Geochem Geophys Geosystems 21:e2019GC008772. https://doi.org/10.1029/ 2019GC008772

Schiano P, David K, Vlastélic I, Gannoun A, Klein M, Nauret F, Bonnand P (2012) Osmium isotope systematics of historical lavas from Piton de la Fournaise (Réunion Island, Indian Ocean). Contrib Mineral Petrol 164:805-820. https://doi.org/10.1007/ s00410-012-0774-0

Shorttle O, Moussallam Y, Hartley ME, Maclennan J, Edmonds M, Murton BJ (2015) Fe-XANES analyses of Reykjanes Ridge basalts: Implications for oceanic crust's role in the solid Earth oxygen cycle. Earth Planet Sci Lett 427:272-285. https://doi.org/ 10.1016/j.epsl.2015.07.017

Sims KWW, Blichert-Toft J, Kyle PR, Pichat S, Gauthier P-J, Blusztajn J, Kelly P, Ball L, Layne G (2008) A Sr, Nd, Hf, and Pb isotope perspective on the genesis and long-term evolution of alkaline magmas from Erebus volcano, Antatctica. Volcanol Erebus Volcano Antarct 177:606-618. https://doi.org/10.1016/j.jvolgeores. 2007.08.006
Sobolev AV, Nikogosian IK (1994) Petrology of long-lived mantle plume magmatism: Hawaii, Pacific, and Reunion Island, Indian Ocean. Petrology 2:111-144

Sobolev AV et al (2007) The amount of recycled crust in sources of mantle-derived melts. Science 316:412-417. https://doi.org/10. 1126/science. 1138113

Sorbadere F, Laurenz V, Frost DJ, Wenz M, Rosenthal A, McCammon C, Rivard C (2018) The behavior of ferric iron during partial melting of peridotite. Geochim Cosmochim Acta 239:235-254. https:// doi.org/10.1016/j.gca.2018.07.019

Stolper DA, Keller CB (2018) A record of deep-ocean dissolved O2 from the oxidation state of iron in submarine basalts. Nature 553:323-327. https://doi.org/10.1038/nature25009

Stolper EM, Shorttle O, Antoshechkina PM, Asimow PD (2020) The effects of solid-solid phase equilibria on the oxygen fugacity of the upper mantle. Am Mineral. https://doi.org/10.2138/am-2020-7162

Stracke A (2012) Earth's heterogeneous mantle: A product of convection-driven interaction between crust and mantle. Chem Geol 330-331:274-299. https://doi.org/10.1016/j.chemgeo.2012.08.007

Stracke A, Bizimis M, Salters VJM (2003) Recycling oceanic crust: Quantitative constraints. Geochem Geophys Geosystems. https:// doi.org/10.1029/2001GC000223

Stracke A, Hofmann AW, Hart SR (2005) FOZO, HIMU, and the rest of the mantle zoo. Geochem Geophys Geosystems. https://doi.org/ 10.1029/2004GC000824

Vlastélic I, Lewin E, Staudacher T (2006) Th/U and other geochemical evidence for the Réunion plume sampling a less differentiated mantle domain. Earth Planet Sci Lett 248:379-393. https://doi.org/ 10.1016/j.eps1.2006.06.003

Widom E, Hoernle KA, Shirey SB, Schmincke HU (1999) Os Isotope systematics in the Canary Islands and Madeira: Lithospheric contamination and mantle plume signatures. J Petrol 40:279-296. https://doi.org/10.1093/pertoj/40.2.279

Zhang HL, Cottrell E, Solheid PA, Kelley KA, Hirschmann MM (2018) Determination of $\mathrm{Fe}^{3+} / \Sigma \mathrm{Fe}$ of XANES basaltic glass standards by Mössbauer spectroscopy and its application to the oxidation state of iron in MORB. Chem Geol 479:166-175. https://doi.org/10. 1016/j.chemgeo.2018.01.006

Zindler A, Hart S (1986) Chemical Geodynamics. Annu Rev Earth Planet Sci 14:493-571. https://doi.org/10.1146/annurev.ea.14. 050186.002425

Publisher's Note Springer Nature remains neutral with regard to jurisdictional claims in published maps and institutional affiliations. 